\title{
Lutas por reconhecimento e vontade de poder: uma afinidade entre Hegel e Nietzsche?"
}

\author{
João Constâncio**
}

\author{
Struggle is part and parcel of the process of \\ recognition itself $^{1}$
}

Resumo: O artigo é uma tentativa de explorar a hipótese controversa de que possa haver uma profunda afinidade - até agora não identificada - entre a concepção de "luta por reconhecimento" [Kampf um Anerkennung] em Hegel e a concepção da dinâmica da "vontade de poder" [Wille zur Macht] em Nietzsche. Esta hipótese diz respeito ao modo como a luta e a dominação estão implícitas na noção hegeliana de reconhecimento, isto é: diz respeito à dinâmica intersubjetiva das formas falhadas de reconhecimento. A luta e a dominação (bem como a violência) são conceitos fundamentais na concepção do reconhecimento em Hegel - mas, ainda assim, conceitos meramente operacionais na obra de Hegel, enquanto em

\footnotetext{
* Agradeço a Robert Pippin, Christoph Schuringa e Simon May os seus encorajadores e estimulantes comentários a uma anterior versão deste artigo. Agradeço também a Rogério Lopes, Oswaldo Giacóia, John Richardson, Paul van Tongeren e Marco Brusotti os seus comentários a uma outra versão (bastante simplificada) deste artigo, que apresentei em Belo Horizonte no $2^{\circ}$ congresso internacional Nietzsche e a tradição filosófica. Um particular obrigado a Katia Hay e Herman Siemens pelos seus comentários a outras versões deste artigo. Agradeço também, como de costume, a inestimável colaboração da Maria João Mayer Branco.
}

*** Professor de Filosofia na Universidade Nova de Lisboa, Portugal.

Correio eletrônico: joaoconst@me.com

1 SIEP, Ludwig. "The Struggle for Recognition: Hegel's Dispute with Hobbes in the Jena Writings". In. O'NEILL, J. (Ed.). Hegel's Dialectic of Desire and Recognition. New York: SUNY, 1996, p. 278. 
Nietzsche se tornam temáticos, porque o conceito de "poder" se torna temático. $\mathrm{O}$ que o artigo procura mostrar é que a hipótese nietzschiana da "vontade de poder" é relevante no debate contemporâneo sobre "reconhecimento e poder" porque permite uma descrição adequada das dinâmicas intersubjetivas em que o reconhecimento recíproco não é alcançado e o que subsiste nelas são relações de luta e dominação, ou seja, vontade de poder qua vontade de dominação. Mas isso só é assim porque a hipótese nietzschiana da "vontade de poder" implica uma "doutrina dos afetos" e, por isso, uma concepção de "poder" [Macht] em termos de "ação à distância", i.e. de influência intersubjetiva mediada por percepções, interpretações e perspectivas. Esta concepção de "poder" implica atribuir ao desejo e à vontade humanas uma natureza "recognitiva", e está longe de implicar a dissolução das relações de poder em processos transsubjetivos de dominação. Daí a afinidade entre Hegel e Nietzsche que o artigo procura evidenciar. Palavras-chave: Hegel - reconhecimento - poder - luta - dominação

\section{Introdução}

Este artigo é uma primeira tentativa de explorar uma hipótese controversa, que pode ser formulada desta forma: há uma profunda afinidade - até agora não identificada - entre a concepção de "luta por reconhecimento" [Kampf um Anerkennung] em Hegel e a concepção da dinâmica da "vontade de poder" [Wille zur Macht] em Nietzsche. É natural que esta hipótese desencadeie reações de rejeição imediata e ceticismo. Pois o reconhecimento parece ser, por definição, incompatível com qualquer tipo de "vontade de poder", sobretudo se se concebe o reconhecimento como envolvendo reconhecimento recíproco de racionalidade (como em Hegel), portanto como envolvendo bem mais do que apenas uma reciprocidade afetiva. Quando dois sujeitos se reconhecem reciprocamente como racionais e, assim, interagem e comunicam um com o outro como iguais (ou seja, como igualmente racionais), o seu relacionamento parece deixar 
de ser uma questão de poder. E se se acredita que, ao lidarem um com o outro dessa forma - isto é, como agentes racionais -, os dois sujeitos não estão iludidos, então não se pode acreditar, ao mesmo tempo, que esses sujeitos ou agentes são, na verdade, "vontade de poder", ou "multiplicidades de vontade de poder" (ou seja, de pulsões irracionais). Além disso, a autoridade de Axel Honneth - o mais proeminente defensor, dentre os filósofos contemporâneos, da noção (basicamente hegeliana) de reconhecimento [Anerkennung] - parece falar claramente contra a hipótese aqui em jogo. Em seu livro, A luta pelo reconhecimento, Honneth refere-se a Nietzsche como se este fosse basicamente um continuador de Hobbes: ao tentar explicar todas as relações humanas em termos de poder, Nietzsche (como Hobbes) não teria compreendido o papel do reconhecimento nas relações sociais ${ }^{2}$. Além disso, em seu livro anterior, A Crítica do Poder, Honneth já havia defendido que a concepção de poder em Nietzsche é incompatível com uma visão intersubjetiva (ou "recognitiva") das sociedades humanas, fazendo equivaler, assim, a posição de Nietzsche à posição de Foucault. $\mathrm{O}$ projeto filosófico de Foucault, segundo Honneth, deve ser visto como uma tentativa de transformar em teoria da sociedade as ideias naturalistas implicadas na teoria de poder de Nietzsche ${ }^{3}$.

É fundamental que o significado e o alcance da minha hipótese de uma "profunda afinidade" sejam claramente estabelecidos desde o início. Em primeiro lugar, é preciso que seja claro que não se trata de defender que Hegel e Nietzsche "dizem a mesma coisa". Minha hipótese diz respeito ao modo como a luta, a dominação e o desejo estão implícitas na noção hegeliana de reconhecimento, isto é: diz respeito à dinâmica intersubjetiva das formas malogradas de

2 Cf. HONNETH, Axel. The Struggle for Recognition, The Moral Grammar of Social Conflicts. Transl. by Joel Anderson. Oxford: Polity Press, 1995, p. 93.

3 Cf. HONNETH, Axel. The Critique of Power, Reflective Stages in a Critical Social Theory. Transl. by Kenneth Baynes. CambridgeMassachussets/London: MIT Press, 1991, p. 154.

$90 \mid$ Cad. Nietzsche, Guarulhos/Porto Seguro, v.37, n.1, p. 88-144, 2016. 
reconhecimento. $\mathrm{O}$ que procuro mostrar é que (contrariamente ao que Honneth sustenta) o conceito de vontade de poder em Nietzsche permite uma descrição adequada dessas dinâmicas intersubjetivas de reconhecimento malogrado. Veremos que essas dinâmicas são moldadas pela natureza recognitiva do desejo e da vontade humanas, de modo que as caracteriza aquilo a que chamarei o "paradoxo da dominação". Veremos também como Nietzsche interpreta as transições de reconhecimentos-malogrados para reconhecimentos recíprocos entre iguais.

Em segundo lugar, talvez seja importante sublinhar desde o início que a força, a violência, a luta, a dominação são conceitos fundamentais na concepção do reconhecimento em Hegel - mas, ainda assim, conceitos operacionais na obra de Hegel, enquanto em Nietzsche se tornam temáticos, porque o conceito de "poder" se torna temático. Assim, a questão levantada aqui não é apenas se o conceito de poder em Nietzsche pode contribuir para esclarecer como "a luta é parte integrante do próprio processo de reconhecimento"4, mas também se o conceito de poder em Nietzsche é teoricamente superior ao de Hegel. Se assim for, então acho que a hipótese de uma afinidade entre Hegel e Nietzsche no que respeita à dinâmica do reconhecimento-malogrado torna-se altamente relevante do ponto de vista filosófico, ou teórico. ${ }^{5}$

Acresce a isso que não deve haver qualquer dúvida de que Nietzsche tem um conceito de reconhecimento - se isso significa um conceito de relações interpessoais e sociais em que dois ou mais sujeitos / pessoas / agentes se reconhecem reciprocamente como

4. SIEP, Ludwig. "The Struggle for Recognition: Hegel's Dispute with Hobbes in the Jena Writings". In. O'NEILL, J. (Ed.). Hegel's Dialectic of Desire and Recognition. New York: SUNY, 1996, p. 278.

5 Uma das principais inspirações deste artigo foi o livro: BRINK, Bert van den/ OWEN, David (Eds.) Recognition and Power: Axel Honneth and the Tradition of Critical Social Theory. Cambridge: Cambridge University Press, 2007. A minha ideia é a de que, apesar de Honneth descartar Nietzsche, este é, na verdade, relevante para o debate contemporâneo sobre "reconhecimento e poder" por causa de seu complexo e sofisticado conceito temático de "poder" [Macht].

Cad. Nietzsche, Guarulhos/Porto Seguro, v.37, n.1, p. 88-144, 2016. 
Constâncio, J.

iguais. (Note-se que, apesar de seus esforços para de-subjetivizar sujeitos, despersonalizar pessoas, e reduzir os agentes a meras associações de pulsões, Nietzsche nunca perde de vista a perspectiva macroscópica ou holística que considera associações particulares de pulsões como organismos, portanto de algum modo como "agentes", "pessoas", "sujeitos", assim como "seres humanos", "indivíduos" etc.) Por exemplo, Nietzsche acredita que, num "rebanho" humano, há agentes que se tornam realmente iguais uns aos outros, e até se regozijam no reconhecimento recíproco da sua igualdade massificada (os "últimos homens" - que talvez "pisquem os olhos" uns aos outros por se darem conta da universalização de seu bovino contentamento - ${ }^{6}$ são um caso particularmente relevante de reconhecimento entre iguais). Mas em comunidades aristocráticas, também indivíduos aristocráticos, nobres "se tratam uns aos outros como iguais" (JGB/ $B M$ 259, KSA 5.207). Também deve ficar claro que Nietzsche enfatiza que a comunicação conceitual, inteligente, ou seja, "racional", é crucial para o reconhecimento recíproco (Cf. $M A$ I/HH I 446, KSA 2.289; FW/GC 54, KSA 3.416; GM/GM, II, 8, KSA 5.305). Por outro lado, Nietzsche sustenta que o que é aqui reconhecido como igual é poder: estados de reconhecimento recíproco são, para Nietzsche, “equilíbrios de poder" (WS/AS 22, KSA 2.555), nos quais as partes envolvidas acreditam ter "um poder aproximadamente igual" (por exemplo: $M A$ I/HH I 92, KSA 2.89; M/A 112, KSA 3.100; JGB/ $B M$ 259, 260, KSA 5.207, 208; GM/GM, I, 10, II, 2, 8, KSA 5.207, 293, 305). Uma outra questão (que não posso abordar neste artigo), porém, é se Nietzsche pode ter sobrestimado o papel do poder em todas as formas de interação e comunicação recíprocas (inclusive na própria formação e desenvolvimento da sociedade), e se, por isso, a concepção da racionalidade em Hegel pode ser "superior" à de Nietzsche.

6 Devo esta ideia (que talvez os últimos homens pisquem o olho uns aos outros) a um comentário do Prof. Oswaldo Giacóia.

92 | Cad. Nietzsche, Guarulhos/Porto Seguro, v.37, n.1, p. 88-144, 2016. 
Em terceiro lugar, o que está em jogo aqui é uma afinidade descritiva, não uma afinidade normativa. Pode ser verdade, por exemplo, que seja impossível conciliar a avaliação normativa negativa que Nietzsche faz da libertação dos "escravos" na modernidade com a avaliação positiva de Hegel - mas isso nada tem que ver com a hipótese aqui levantada. Minha preocupação é determinar se há uma afinidade no modo como Hegel e Nietzsche descrevem tal libertação, não é determinar como a avaliam de um ponto de vista normativo. Hegel e Nietzsche descrevem a modernidade como uma época em que a sociedade evolui para um máximo de igualdade - mas, em seguida, avaliam isso de forma diferente: como o progresso em direção à liberdade na forma da "reconciliação" ou reconhecimento recíproco no caso de Hegel, e como décadence e enfraquecimento da "vontade de poder" da nossa espécie no caso de Nietzsche. Mas também não é esta a afinidade descritiva que tenho em mente: a minha hipótese é de que há uma afinidade a um nível mais profundo, uma afinidade no modo como Hegel e Nietzsche descrevem psicológica e sociologicamente as relações interpessoais e sociais, uma afinidade no modo como descrevem não tanto os estados finais de reconhecimento alcançado, a igualdade ou reciprocidade, quanto a dinâmica das interações e dos processos intersubjetivos que não conseguem chegar a - i.e., que falham - um reconhecimento recíproco.

\section{O conceito de reconhecimento em Hegel}

Comecemos por considerar a famosa descrição de Hegel de uma "luta de vida ou morte" na Fenomenologia do Espírito (PhS). Esta luta introduz o conceito de reconhecimento na $P h S$, porque é o evento que acaba por conduzir a uma primeira forma de reconhecimento unilateral, assimétrico - ou melhor, reconhecimento-malogrado, como veremos: a relação entre um senhor e um escravo $(P h S \S 187-189$; TWA 3, p. 147-149). 
Constâncio, J.

Esta luta de vida ou morte é a versão hegeliana do "estado de natureza" [Naturzustand], tal como Hegel explicitamente refere na Enzyklopädie (Enz. §432). Mas é um estado de natureza diferente daquele que é descrito nas teorias do contrato social, em particular do estado de natureza descrito por Hobbes. Na representação que Hegel faz de um tempo anterior à existência de quaisquer normas e instituições sociais, não há uma "guerra de todos contra todos", pois os seres humanos que vivem nessa época já são seres sociais. Tal como Hegel torna particularmente claro nos seus escritos de Jena, a sua ideia é a de que devemos postular a existência de afetos coletivos, comunitários já na origem da sociedade, especialmente o amor entre os membros de famílias, e, portanto, também um "eu” social, ou seja, um "eu" já moldado por laços familiares, especialmente por laços pré-contratuais de amor - ou, como Hegel escreve mais tarde, numa das mais famosas frases da $P h S$ : "um eu que é um nós e um nós que é um eu” (PhS §176; TWA 3, p. 143). ${ }^{7} \mathrm{E}$, no entanto, se alguém quiser compreender como surgiu a sociedade, e como foi que, a partir de um estado inicial pré-contratual e pré-institucional, a sociedade evoluiu, gradualmente, até aos dias de hoje - ou seja, se alguém quiser compreender todo o caminho do "espírito" desde os tempos primordiais em que os seres humanos viviam como nômades em famílias primitivas até aos tempos da (alegada) "reconciliação"

7 Sobre este aspecto dos escritos de Jena de Hegel, veja-se, em particular, SIEP, Ludwig. Anerkennung als Prinzip der praktischen Philosophie: Untersuchungen zu Hegels Jenaer Philosophie des Geistes. Freiburg: Alber Verlag, 1979; WILLIAMS, Robert R. Recognition: Fichte and Hegel on the Other. New York: SUNY, 1992; HONNETH, Axel. The Struggle for Recognition, The Moral Grammar of Social Conflicts. Transl. by Joel Anderson. Oxford: Polity Press, 1995; HARRIS, Henry S. "The Concept of Recognition in Hegel's Jena Manuscripts". In. O'Neill, J. (Ed.). Hegel's Dialectic of Desire and Recognition. New York: SUNY, 1996, pp. 233-252; WILLIAMS, Robert R. Hegel's Ethics of Recognition. Berkeley/ Los Angeles/ London: University of California Press, 1997. (As traduções de citações das obras de Hegel são minhas).

94 | Cad. Nietzsche, Guarulhos/Porto Seguro, v.37, n.1, p. 88-144, 2016. 
[Versöhnung] do espírito consigo mesmo no mundo moderno -, é preciso conceber uma luta entre pelo menos dois dos indivíduos que viveram naqueles tempos primordiais. Essa é precisamente a "luta de vida ou morte", um duelo no qual dois indivíduos lutam até a morte, ou seja, arriscam perder a vida, arriscam perder a sua existência natural como corpos individuais, a sua corporeidade [Leiblichkeit], e fazem-no por uma questão de reconhecimento. Mas por que dois indivíduos empreenderiam alguma vez uma tal luta? E o que exatamente significa lutar por "reconhecimento"?

Segundo a Fenomenologia, cada um dos participantes no duelo quer afirmar-se, provar o seu valor, tornar-se certo de si mesmo, tornar-se independente, e, assim, alcançar a consciência de sua liberdade. Este parece ser o "desejo" de cada um deles enquanto "autoconsciência" (ou na medida em que cada um deles é uma "consciência" que agora quer tornar-se consciente de si mesma). Sendo assim, cada um dos participantes no duelo luta por reconhecimento porque "a autoconsciência alcança a sua satisfação apenas em outra autoconsciência" (PhS §175; TWA 3, p. 144), ou, por outras palavras, "a autoconsciência existe em si e por si porque e por meio da sua existência em si e por si para outra autoconsciência; ou seja, existe apenas na medida em que é reconhecida" ( $P h S$ §178; TWA 3, p. 145). A fim de se afirmar, provar o seu valor, tornar-se certo de si mesmo, tornar-se independente, alcançar a consciência de sua liberdade, cada um dos participantes no duelo precisa ser reconhecido pelo outro. O seu "eu" (o "si próprio", o "auto" da sua "autoconsciência"), bem como o seu valor, sua certeza de si mesmo, sua independência, sua liberdade têm de se tornar verdades intersubjetivas - ou seja, fatos que não só o próprio crê serem fatos, mas também as outras pessoas tomam por fatos numa rede intersubjetiva de reconhecimento recíproco. Caso contrário, todas aquelas aspirações continuariam a ser uma mera série de estados mentais cartesianos sem qualquer substância, "essências que desaparecem" [verschwindende Wesen] 
Constâncio, J.

(PhS §175; TWA 3, p. 138), instantes e representações meramente subjetivas cuja realidade continuaria por provar. E isso é, note-se, o que acontece com a consciência se, ao fazer-se "corpo" e tornar-se "desejo", busca satisfação apenas em objetos: cada objeto que se segue a um outro pode, talvez, satisfazer o desejo feito corpo, mas no momento em que o faz também é negado, cancelado, anulado, consumido e, portanto, não satisfaz o desejo da autoconsciência de alcançar autoafirmação, certeza de si, independência e liberdade. Só o reconhecimento por um outro sujeito pode dar este tipo de satisfação - "a autoconsciência alcança a sua satisfação apenas em outra autoconsciência" (PhS §175; TWA 3, p. 144).

Por outro lado, ambos os participantes no duelo são, desde o início, seres sociais. Antes de se confrontarem um com o outro e começarem a lutar, não existem como sujeitos solipsistas ou cartesianas, autoconsciências isoladas que ainda precisassem provar para si próprias a existência de outros sujeitos e de um mundo exterior. Se precisam provar alguma coisa no seu duelo, é até o contrário, ou seja, que a sua certeza de si mesmos não é uma ilusão subjetiva. Até certo ponto, isso é algo que eles já confirmaram no contexto de suas vidas familiares. A luta pelo reconhecimento da "luta de vida ou morte" já pressupõe um grau mínimo de reconhecimento, a identificação prévia de um "eu" com um "nós", uma identidade social já anteriormente constituída. Mas (a) este grau mínimo de reconhecimento não foi conquistado numa luta, pelo menos não no tipo de luta de vida ou morte que Hegel pensa ser paradigmática das lutas que levam a mudanças sociais. Além disso, (b) o tipo de autoafirmação que surge do reconhecimento no contexto da vida familiar primitiva é demasiado paroquial: não é ainda a autoafirmação de uma autoconsciência como autoconsciência, menos ainda como "pessoa", como "cidadão", ou como "ser humano", ou como qualquer outro "universal" deste tipo ("sujeito", "eu" etc.). (c) Embora o participante no duelo já se identifique com um "nós", esta identificação 
é fundamentalmente afetiva, de forma que o seu sentimento de si, a sua independência e liberdade ainda são demasiado fracas para não serem abaladas, questionadas, perturbadas, desafiadas pela presença de um "outro", um "estrangeiro" que vem de fora da família. E isso é precisamente o que lança a luta de vida ou morte primordial. Podemos imaginar (embora Hegel não o explicite) que os participantes no duelo interpretam a sua conduta como uma luta pela honra de seus respectivos clãs, por exemplo. Note-se novamente como isso é diferente da guerra hobbesiana de todos contra todos. ${ }^{8}$

Precisaremos pensar o modo como Hegel concebe uma forma de reconhecimento não-paroquial, perfeita - e perfeitamente recíproca. Veremos que a concepção de uma tal forma de reconhecimento assenta no conceito hegeliano de razão e da racionalidade. Mas, primeiro, consideremos o modo como termina a luta de vida ou morte. $\mathrm{O}$ resultado de uma luta de vida ou morte pode ser simplesmente negativo do ponto de vista da aspiração de ambos os contendores à autoafirmação, certeza de si, independência e liberdade. Se nenhum dos participantes no duelo consente em algum momento ser subjugado pelo outro e ambos lutam até à morte real de um deles; se nenhum deles em algum momento teme a morte, ou seja, se nenhum deles em algum momento prefere preservar a sua vida a continuar a arriscá-la, então não resulta da luta sequer um grau mínimo de reconhecimento recíproco. O duelo terá um morto e um vencedor, mas este não será capaz de continuar buscando a satisfação em outra

8 Para um resumo da luta de vida ou morte, cf. WILLIAMS, Robert R. Tragedy, Recognition, and the Death of God. Oxford: Oxford University Press, 2012, p. 34-38, 46-47. Williams mostra que a interpretação subjetivista do reconhecimento em Hegel exposta por Deleuze no seu livro sobre Nietzsche é um erro (p. 40-44). A interpretação errada de Deleuze é, provavelmente, responsável pelo fato de muitos estudiosos de Nietzsche pressuporem que as lutas por reconhecimento em Hegel não teriam nada que ver com Nietzsche. Quanto à crítica da teoria do contrato social em Hegel, deve notar-se que ela vai muito além do que acima escrevi. Para um excelente tratamento desta questão, cf. PATTEN, Allen. "Social Contract Theory and the Politics of Recognition in Hegel's Political Philosophy". In. WILLIAMS, R. R. (ed). Beyond Liberalism and Communitarianism: Studies in Hegel's Philosophy of Right. New York: SUNY, 2001. 
Constâncio, J.

autoconsciência (pois a outra autoconsciência terá deixado de ser uma autoconsciência).

Para se conceber uma transição do estado de natureza para a sociedade, é preciso imaginar outro tipo de resultado; não necessariamente um resultado positivo, mas pelo menos um resultado ambivalentemente (e, portanto, "dialeticamente") negativo, um resultado que envolva algum tipo de progresso e, pelo menos, algum tipo de potencial para a autossubversão. Desta forma, somos convidados a imaginar a possibilidade de que o duelo primordial de vida ou morte termine numa relação senhor/escravo. $\mathrm{O}$ que isto significa, no entanto, é que somos novamente convidados a conceber uma luta cujo verdadeiro objetivo é o reconhecimento, mas que não termina em reconhecimento, especialmente não em reciprocidade, não num reconhecimento perfeito (ou reconciliação). Pois uma relação senhor/escravo é, sem dúvida, uma forma de fracasso do reconhecimento recíproco, um caso de reconhecimento-malogrado: (a) o senhor não reconhece o outro como um outro eu, ou como uma vontade igual à sua, ou igualmente independente, ou seja: o senhor tornou-se, até certo ponto, uma "autoconsciência independente", mas não reconhece a existência do escravo como a existência de outra "autoconsciência independente"; (b) e, assim, o escravo torna-se um mero instrumento da autoconsciência do senhor, é reificado, tornase uma "coisa", uma "autoconsciência dependente". O escravo não reconhece sua própria autoconsciência como uma autoconsciência independente que poderia reconhecer no senhor a existência de uma outra autoconsciência independente. Nem a autoconsciência independente do senhor, nem a autoconsciência dependente do escravo encontra "satisfação (...) em outra autoconsciência" (PhS $\S 175$; TWA 3, p. 144).

E, no entanto, este resultado não é simplesmente negativo. Em primeiro lugar, porque esta já é uma relação entre duas autoconsciências. Na relação senhor/escravo, o escravo é "reificado", 
mas essa reificação não é absoluta: a autoconsciência do escravo foi negada, mas não foi anulada (como teria sido se o escravo tivesse morrido). $\mathrm{O}$ escravo permanece vulnerável e não-indiferente ao senhor, e a sua experiência pessoal, subjetiva ("na primeira pessoa") de dependência, de desigualdade e de alienação é de fato uma nova maneira de experimentar a necessidade de reconhecimento, ou seja, a necessidade de buscar a autoafirmação e "satisfação" em outra autoconsciência. (Pelo menos potencialmente, a relação entre o senhor e o escravo permanece intersubjetiva, pois resta algum espaço para o senhor ser suscetível, vulnerável, não-indiferente à vontade do escravo, ainda que num grau mínimo. Segundo a fenomenologia de Hegel, no entanto, o peso do desenvolvimento "dialético" do resto da história recai totalmente sobre o escravo.)

Em segundo lugar, a relação senhor/escravo é de fato uma primeira forma de organização social: a primeira instituição e transição para a sociedade. A relação senhor/escravo põe fim à enorme violência que prevalecia no estado de natureza quasi-hobbesiano da luta de vida ou morte. Sem dúvida, o que agora é institucionalizado é uma relação desigual com base na coerção, mas o ponto decisivo é que essa relação se tornou uma verdade intersubjetiva. É uma realidade social, e não uma mera representação que aparece e logo desaparece na autoconsciência de um sujeito isolado.

Em terceiro lugar, a relação senhor/escravo é um paradigma, um padrão de mudança social. A origem e padrão de mudança social em geral não é o "contrato social", mas sim a relação senhor/escravo. A sociedade se desenvolve por meio da institucionalização dos resultados de lutas por reconhecimento, o desenvolvimento da sociedade é, em primeiro lugar e em sua maior parte, uma sucessão de lutas que, como o duelo de vida ou morte primordial, conduzem (se não à destruição e à pura violência) a sucessivas institucionalizações de formas de reconhecimento unilaterais, assimétricas, coercivas e basicamente falhadas. Mas cada uma dessas sucessivas institucionalizações tem 
em si as sementes de sua própria autossubversão. A razão pela qual, segundo Hegel, ao longo da história humana se foi desenvolvendo uma progressiva (e relativa) substituição da coerção pela igualdade e pelo reconhecimento recíproco é porque as formas elementares da relação senhor/escravo evoluíram gradualmente e acabaram por progredir no sentido de se transformarem em instituições de liberdade. Foi este progresso que tornou possível uma "reconciliação" completa do "espírito" consigo mesmo no mundo moderno - o mundo democraticamente organizado.

Para os nossos fins neste artigo, o ponto crucial, no entanto, é estabelecer que a relação senhor/escravo é o modo como Hegel conceitualiza a dominação. E se isto significa que a dominação é, para Hegel, equivalente ao reconhecimento-malogrado, significa também que a dominação é uma relação de poder unilateral e assimétrica em que uma vontade humana se torna senhora de outra vontade humana e, portanto, reifica esta outra vontade (ou esta outra autoconsciência desejante). Ao nível interpessoal (que Hegel, ao contar a história do duelo de vida ou morte, apresenta como paradigmático), essas duas vontades são individuais; ao nível social, são coletivas (ou seja, são as "vontades" de classes, povos, raças, sexos etc.). Além disso, também deve ser claro que a dominação como reconhecimentomalogrado assume muitas formas, como por exemplo, a opressão, a marginalização, a exclusão social, a escravidão em sentido literal etc.

O mais importante, porém, é o fato de a relação senhor/escravo ser a maneira como Hegel conceitualiza a mediação simbólica que está implicada na dominação qua reconhecimento-malogrado. Se um dos participantes no duelo primordial tivesse morrido (ou se ambos tivessem morrido), nenhum progresso teria sido alcançado em termos de satisfação da autoafirmação da autoconsciência, ou seja, em termos de reconhecimento. Mas na relação senhor/escravo não só a autoafirmação do senhor é mediada pelo outro (ou seja, pelo escravo), como também é simbolicamente mediada. Pois na 
transição da luta de vida ou morte para a relação senhor/escravo uma pura, bruta relação de poder foi transformada numa relação de poder simbolicamente mediada, ou seja, em uma interação entre duas vontades humanas que agora implica comunicação inteligente, conceitual e, na verdade, compreensão e aceitação recíproca de certas normas ou regras de conduta. Na medida em que a interação entre os dois participantes no duelo primordial é uma relação senhor/ escravo, ela ainda repousa na coerção, não se tornou uma relação livre entre eles (pois não se pode dizer, de forma alguma, que seja igualmente consentida por ambos) - mas tornou-se, ainda assim, uma interação regulamentada, mesmo que apenas unilateralmente, ou mesmo que apenas regulada de forma desigual. Do ponto de vista prático, a verdade é que o escravo se resignou a ser subjugado pelo senhor: no final, considerou a sua vida pelo menos tão importante como o reconhecimento e, por isso, preferiu, ao contrário do senhor, ser escravizado a continuar a arriscar morrer.

Tal como escreve Alexandre Kojève, a relação senhor/escravo é uma relação de "autoridade" fundada "no risco"9. A interação entre ambos pressupõe agora a autoridade do senhor, de modo que este último já não precisa (ou quase nunca precisa) fazer uso da violência a fim de ser obedecido. A interação entre ambos, embora ainda baseada na coerção, é agora, em grande medida, regulada pela identificação de ambos com seus novos papéis sociais, os quais reformularam suas identidades mais íntimas: um deles se tornou de fato "o senhor", o outro "o escravo".

Para Hegel, isso significa que há racionalidade na forma como a realidade social (e interpessoal) se desenvolve (e especialmente na forma como ela progride em direção à liberdade). A realidade social humana envolve conceitos e, portanto, a mediação de normas ou regras que certos conceitos implicam. Na verdade, a racionalidade é uma

9 KOJÈVE, Alexandre. The Notion of Authority (A Brief Presentation). London/ New York: Verso, 2014, p. 16-18. 
questão crucial para o reconhecimento já ao nível fenomenológico mais elementar. Na fenomenologia da consciência de si, o fundamento da afirmação de que "a autoconsciência existe em si e por si porque e por meio da sua existência em si e por si para outra autoconsciência; ou seja, existe apenas na medida em que é reconhecida" $(P h S \S 178$; TWA 3, p. 145) é, em última análise, a concepção do indivíduo consciente de si como um sujeito racional. Um sujeito é racional na medida em que é sensível a razões e age em função de certas razões para agir. Mas, para ser racional, tem de habitar (para usar a expressão Sellarsiana de Terry Pinkard) um "espaço de razões"10. E um espaço de razões - um espaço normativo - é sempre já um espaço social: é precisamente o tipo de espaço intersubjetivo em que um sujeito é reconhecido como racional por outros sujeitos. Num espaço deste tipo, um sujeito é "convocado" e solicitada a dar razões para suas ações: pensa e age como um ser cujos compromissos e ações têm de ter um propósito que se conjugue com os propósitos de outros; num espaço deste tipo, um sujeito é confrontado com argumentos, aspirações, reivindicações que outros fazem, com regras e leis tendo em vista quais é suposto que se justifique racionalmente o que se fez, se está fazendo ou vai fazer. Um sujeito é, assim, reconhecido pelos outros como racional enquanto reconhece os outros como racionais, $\mathrm{e}$ é assim que alguém se torna um agente humano, um sujeito humano que conhece e age, um cognoscente e agente, o sujeito racional a quem pertence uma determinada série de pensamentos e ações. A subjetividade é, portanto, tornada possível pelo reconhecimento intersubjetivo. $^{11}$

10 Cf. PINKARD, Terry. Hegel's Phenomenology. The Sociality of Reason. Cambridge: Cambridge University Press, 1994.

11 Veja-se, especialmente, a interpretação do reconhecimento nas obras de Terry Pinkard e Robert B. Pippin: PINKARD, Terry. Hegel's Phenomenology, op. cit.; PIPPIN, Robert B. Hegel's Naturalism. Mind, Nature, and the Final Ends of Life. Oxford: Oxford University Press, 2012; PIPPIN, Robert B. Hegel's Practical Philosophy. Rational Agency as Ethical Life. Cambridge: Cambridge University Press, 2008; Hegel on Self-consciousness. Desire and Death in the Phenomenology of 
O ideal hegeliano da reconciliação, ou do reconhecimento recíproco e da igualdade perfeita, passa por esta concepção da subjetividade e da racionalidade. $\mathrm{O}$ reconhecimento será sempre paroquial e imperfeito se não consistir numa relação em que um sujeito racional se reconheça no outro, isto é, reconheça o outro não apenas como um outro sujeito, mas também como um outro sujeito racional, e ao mesmo tempo seja reconhecido pelo outro como um sujeito tão racional como ele, i.e. igualmente racional. Mas, ao tomar o outro como um sujeito racional, cada sujeito racional faz, na verdade, mais do que reconhecer uma igualdade fundamental entre si e o outro, pois cada um reconhece também uma diferença: cada um é reciprocamente afirmado como um igual, mas também como um ser independente, uma autoconsciência independente. Reconhecimento qua reconciliação designa um tipo de relação social ou interpessoal em que não só cada sujeito é reciprocamente afirmado ("posto") como um "eu" universal (o "eu" de uma subjetividade racional), mas também como um "eu" particular (um sujeito individual).

Neste tipo de reconhecimento, o "eu" da autoconsciência torna-se um "nós" de uma forma que não a limita. $\mathrm{O}$ outro que está incluído neste "nós" já não é um impedimento ou obstáculo à autoafirmação do eu, ou à certeza de si mesmo e do seu valor, à sua independência e liberdade. Pelo contrário, o outro tornou-se agora uma condição de tudo isso. ${ }^{12}$

Este tipo de reconhecimento recíproco entre sujeitos racionais que se reconhecem reciprocamente como sujeitos racionais é, de fato, o tipo ideal de reconhecimento para Hegel. Note-se como tal ideal inclui, ou é em parte, um ideal de comunicação racional e justificação

Spirit. Princeton and Oxford: Princeton University Press, 2011.

12 É esta a diferença crucial entre o reconhecimento hegeliano e o fichtiano: cf. SIEP, Ludwig. Anerkennung als Prinzip der praktischen Philosophie, op. Cit.; PIPPIN, Robert B. Hegel's Practical Philosophy. Rational Agency as Ethical Life. Cambridge: Cambridge University Press, 2008; e em particular WILLIAMS, Robert R. Recognition: Fichte and Hegel on the Other, op. cit., p. 63-64, 78, 82-83, 88-89. 
racional de normas sociais. De certo modo, o projeto de Hegel é em última análise o projeto da justificação racional do mundo moderno e das instituições modernas de liberdade. O Estado moderno, a institucionalização moderna da igualdade de direitos, da democracia etc. representam, para ele, não apenas a superação da dominação por meio do reconhecimento, mas também (e mais crucialmente) a justificação de tal superação em termos de reconhecimento recíproco de racionalidade. ${ }^{13}$

A racionalidade aqui em jogo não é a pura racionalidade de um sujeito cartesiano ou kantiano. É, antes, a racionalidade da autoconsciência feita corpo, e, na verdade, de uma autoconsciência desejante ("a autoconsciência é desejo [Begierde]", PhS §174; TWA 3 , p. 142). O reconhecimento hegeliano é uma teoria do desejo, e descreve a transição do desejo animal para um tipo de desejo propriamente humano. Este último é diferente do desejo animal para ser inteiramente moldado pela intersubjetividade e pelo reconhecimento. Como Kojève mostrou, pelo menos uma parte do que Hegel quer dizer na sua fenomenologia da autoconsciência é que o desejo humano é “dirigido a um objeto não-natural”, ou seja, dirigido ao "desejo ele próprio"14. 0 desejo humano tem sempre o desejo do outro como seu objeto. Os seres humanos, ao contrário dos outros animais, desejam ser desejados - isto é, desejam ser correspondidos e, portanto, devidamente reconhecidos pelo outro. Os

13 Esta é a dimensão do reconhecimento mais fortemente sublinhada em PIPPIN, Robert B. Hegel's Practical Philosophy, op. cit. Sobre o conceito de reconciliação em Hegel e os estádios que conduzem à liberdade pessoal, moral e social no mundo moderno, cf. HARDIMON, Michael O. Hegel's Social Philosophy: The Project of Reconciliation. Cambridge: Cambridge University Press, 1994; e NEUHOUSER, Frederick. Foundations of Hegel's Social Theory. Cambridge MA: Cambridge University Press, 2000; NEUHOUSER, Frederick. "Hegel's Social Philosophy". In. BEISER, Frederick C. The Cambridge Companion to Hegel and Nineteenth-Century Philosophy. Cambridge: Cambridge University Press, 2008, p-204-229.

14 KOJÈVE, Alexandre. Introduction to the Reading of Hegel. Lectures on the Phenomenology of Spirit. assembled by Raymond Queneau, edited by Allan Bloom, translated by James H. Nichols, Jr. Ithaca and London: Cornell University Press, 1980, p. 5.

$104 \mid$ Cad. Nietzsche, Guarulhos/Porto Seguro, v.37, n.1, p. 88-144, 2016. 
seres humanos buscam "satisfação apenas em outra autoconsciência" (PhS §175; TWA 3, p. 144). É isso que leva ao reconhecimento do outro, porque leva ao reconhecimento do desejo do outro. E isso, por sua vez, muda a natureza de cada possível objeto de desejo que aparece dentro do espaço social habitado pelos seres humanos: objetos que seriam "perfeitamente inúteis do ponto de vista biológico (como uma medalha ou a bandeira do inimigo)"15 tornam-se objetos de desejo, por serem desejados por outros. E, nos casos de perfeito reconhecimento recíproco entre indivíduos racionais, a interação intersubjetiva torna-se livre: ninguém está sendo coagido a fazer coisa alguma - a coerção desapareceu magicamente do reino da autoconsciência humana e do desejo. Ou, por outras palavras, o verdadeiro reconhecimento depende de uma Freigabe: cada uma das partes envolvidas tem de deixar a outra ser, libertando-a, assim, de qualquer forma de coerção. ${ }^{16}$ Deste modo, as interações humanas tornam-se éticas [sittlich], a reconciliação é alcançada e a dominação é "suprassumida" [aufgehoben], transformando-se em liberdade. ${ }^{17}$

Avancemos agora para uma primeira aproximação à hipótese da vontade de poder em Nietzsche. A maior parte das interpretações desta hipótese presume que ela implica que, em todas as formas de interação humana, o comportamento é motivado por uma pulsão individualista ou egoísta de possuir ou dominar o outro, e, portanto, que a ocorrência de reconhecimento recíproco na interação humana é sempre ilusória: mesmo no caso de amor, não é possível o reconhecimento da alteridade (ou "outridade") do outro. Se, no entanto, olharmos para o que Nietzsche tem a dizer precisamente

15 Id. Ibdem, p. 3-30.

16 Cf. WILLIAMS, Robert R. Hegel's Ethics of Recognition, op. cit, p. 84-88.

17 Sobre o complexo conceito de liberdade em Hegel e os diferentes estádios da sua realização, cf. HARDIMON, Michael O. Hegel's Social Philosophy, op. cit; NEUHOUSER, Frederick. Foundations of Hegel's Social Theory, op. cit.; NEUHOUSER, Frederick. "Hegel's Social Philosophy", op. cit.; LOSURDO, Domenico. Hegel and the Freedom of Moderns. Durham and London: Duke University Press, 2004; Pippin (2008). 
Constâncio, J.

sobre o amor, podemos talvez começar a perceber o quão sutil é sua concepção de "poder" e, portanto, sua concepção da interação humana em termos de "vontade de poder".

\section{Nietzsche: o amor e a impossibilidade da "posse"}

Há muitas passagens em que Nietzsche descreve o amor em termos de poder. Por exemplo, em A gaia ciência, particularmente no aforismo "As coisas que chamamos de amor", Nietzsche apresenta o amor como um sentimento que não pode ser adequadamente distinguido da ganância [Habsucht]: amor, afirma, é uma questão de "propriedade", ou "posse", um querer assimilar o outro "em nós mesmos", e o amor sexual é, muito claramente, uma "ânsia por nova propriedade", uma vontade de ganhar "posse incondicional" sobre o corpo e a alma do outro, um "selvagem cobiça", que é, talvez, "a expressão mais direta do egoísmo", e não é certamente "o oposto do egoísmo" $\left(F W / G C\right.$ 14, KSA 3.386). ${ }^{18}$

No entanto, a questão é, naturalmente, o que quer Nietzsche realmente dizer com "poder" quando escreve que o amor é uma vontade de ganhar "poder" sobre o outro. O seguinte aforismo de Além de bem e mal, por exemplo, deixa claro que Nietzsche não concebe o poder como sinónimo da posse física e violenta do outro:

A diversidade humana não se revela apenas na diversidade das tábuas de bens, ou seja, no fato de os seres humanos considerarem desejáveis diferentes bens e discordarem quanto ao seu valor ser maior ou menor, quanto à ordem hierárquica dos bens reconhecidos em comum; essa diversidade revela-se ainda mais naquilo que conta para os seres humanos como o verdadeiro ter e possuir. Quando se trata de uma mulher, por exemplo, um homem modesto considera o dispor do seu corpo e do uso sexual como sinais suficientes e satisfatórios do ter, do possuir. Outro homem com uma sede de posse mais desconfiada e exigente verá aqui o "ponto de interrogação", a mera aparência de um tal ter, e quererá examinar mais de perto, sobretudo a

18 Tradução de Paulo César de Souza. Doravante, PCS.

$106 \mid$ Cad. Nietzsche, Guarulhos/Porto Seguro, v.37, n.1, p. 88-144, 2016. 
fim de saber se a mulher não apenas se entrega a ele, mas também se ela renuncia, por ele, àquilo que ela tem ou gostaria de ter - : só isso contará, para ele, como "posse". Mas mesmo isso não satisfaz a desconfiança e o querer possuir de um terceiro homem, que pergunta se a mulher que abre mão de tudo por sua causa não está fazendo isso por algum tipo de fantasma dele: quer ser completamente, até mesmo abissalmente, conhecido, a fim de poder, de todo, ser amado; ousa deixar que alguém o adivinhe -. Este homem não sentirá que possui sua amada totalmente enquanto ela abrigar ilusões acerca ele, até que ela o ame tanto pelo que há nele de diabólico e pela sua oculta inesgotabilidade quanto pela sua bondade, paciência e espiritualidade (JGB/BM 194, KSA 5.115).

Nietzsche concebe aqui o amor entre um homem e uma mulher em termos de posse e poder, e contudo deixa imediatamente claro que considera a posse física apenas “a mera aparência” de posse. $\mathrm{O}$ segundo amante nesta história - aquele que tem "uma sede de posse mais desconfiada e exigente" e, por isso, vê o "ponto de interrogação" na ideia de posse - preocupa-se com o fato de não dispor de uma prova de que realmente possua a amada. A fim de sentir que realmente a possui, precisa de que ela abra mão, renuncie, por ele, "àquilo que ela tem ou gostaria de ter". Ele precisa de um sacrifício dela como um sinal de posse, porque sente que, de outra forma, não pode ter a certeza de ter poder sobre ela. Isso significa que ele se preocupa com o que está por detrás dos sinais de amor que recebe da parte dela, ou que, de fato, se preocupa com o modo como é percebido e desejado por ela. Mesmo que de uma forma confusa, ele percebe que, ao aspirar possuí-la, aspira a possuir todo o seu ser, ou, mais precisamente, a sua "vontade" - e que isso implica (ou implicaria) ser percebido por ela como o objeto de desejo dela. Essa é precisamente a lógica da concepção do desejo humano como desejo recognitivo em Hegel. Dado que o desejo humano tem o desejo do outro como objeto, torna-se um desejo de ser reconhecido pelo outro que não pode dispensar também o reconhecer o outro, isto é, reconhecer o desejo do outro. 
Constâncio, J.

$\mathrm{O}$ caso do terceiro amante no aforismo de Nietzsche obedece a esta mesma lógica de reconhecimento, e este é, naturalmente, o caso mais interessante. Este terceiro amante vai um passo além do segundo, pois sente que, a fim de realmente possuir a mulher amada, tem de revelar a todo o seu ser. Em vez de (ou além de) exigir um sacrifício da mulher amada, exige um sacrifício de si mesmo. Pois obriga-se ao doloroso esforço de se revelar sem a proteção de uma máscara social: "até que ela não abrigue ilusões sobre ele, até que ela o ame tanto pelo que há nele de diabólico e pela sua oculta inesgotabilidade quanto pela sua bondade, paciência e espiritualidade" (JGB/BM 194, KSA 5.115). E esta é, mais uma vez, a lógica do desejo como luta por reconhecimento. Para alcançar a posse do desejo dela, ele sente que deve ser plenamente reconhecido por ela - mesmo nas suas características mais negras -, e quanto mais ele consegue, desta forma, ser reconhecido por ela, também mais ele a reconhece a ela em troca. $\mathrm{O}$ que o perturba é a possibilidade de que ela poderia desejar apenas um "fantasma", uma "versão fantasiosa" do que ele é. Por isso, renuncia ao seu orgulho e tudo faz para ser devidamente reconhecido por ela, ou seja, propriamente percebido e desejado por ela. Quanto mais ele consegue isso, mais se pode dizer que ele está sob a influência dela - ou seja, mais ele atende ao que ela é e, por isso, mais poderosa ela se torna em relação a ele.

E isto não é ainda o fim da história. Este terceiro amante arrisca tudo para aumentar o seu poder sobre sua amada. Para alcançar a plena posse dela, arrisca perder o grau de posse que já alcançou. E este aspecto é conforme com o fato de Nietzsche repetidamente afirmar que a dinâmica da "vontade de poder" - e, em particular, a dinâmica do desejo como "vontade de poder" - não é uma dinâmica de preservação ou conservação, mas sim de autossuperação e, portanto, de risco, como veremos na próxima seção.

Assim, tal como Hegel, Nietzsche se opõe ao hedonismo e, especialmente, à tese de que a ação humana seja motivada por uma pulsão homeostática de preservação de estados de prazer e de

108 Cad. Nietzsche, Guarulhos/Porto Seguro, v.37, n.1, p. 88-144, 2016. 
aversão de estados de dor. Para Nietzsche, o prazer é basicamente um efeito colateral da obtenção de poder. Sentimos prazer quando superamos uma resistência à nossa vontade de poder, e isso explica o fato psicológico de que muitas vezes procuramos a dor. Enquanto "vontades de poder", procuramos muitas vezes confrontar-nos com resistências - com resistências dolorosas -, a fim de superarmos o grau de poder e o sentimento de poder de que dispomos num dado momento do tempo.

$\mathrm{O}$ caso do terceiro amante no aforismo de Além de bem e mal deixa claro que o amor como um "desejo ganancioso" de possuir o outro é "vontade de poder". Ao buscar a "posse", o terceiro amante é levado a perceber que "o outro", a mulher amada, resiste à posse, mas isso é precisamente o que o faz buscar resistências e arriscar tudo. Porque se sente sem poder, busca mais poder - independentemente da dor que isso possa provocar nele. Foi apanhado na dinâmica da vontade de poder, a dinâmica do "crescimento", "autossuperação" e necessidade de mais e mais poder.

Mas o que isso também implica é que, apesar de um sentimento de posse ser perfeitamente possível, a verdadeira posse é impossível. À medida que o poder do terceiro amante sobre a mulher amada aumenta, o poder dela sobre ele também aumenta. Num caso como este, ambas as partes (isto é, ambos os centros de poder ou força) aumentam reciprocamente o poder de uma sobre a outra. Mesmo se, neste processo, um deles se torna temporariamente mais poderoso do que o outro e é basicamente aquele que "comanda" enquanto o outro "obedece", a resistência deste que obedece permanece. Pois a resistência, como veremos mais detalhadamente na próxima seção, pertence à essência do poder e do sentimento de poder.

Em A gaia ciência, Nietzsche expressa a impossibilidade da verdadeira posse por meio de um conceito que foi buscar à filosofia antiga e que, como ele bem sabia, desempenhou um papel importante na física moderna: o conceito de "ação à distância". Supostamente, a gravidade e o magnetismo são instâncias desse tipo de ação. Em 
Constâncio, J.

ambos os casos, um corpo físico atrai outro corpo físico sem tocá-lo, como se uma força ou poder dentro do primeiro agisse sobre uma força ou poder dentro do segundo. Roger Boscovich - cuja influência sobre Nietzsche foi imensa - generalizou essa ideia na Física e tentou provar que os corpos físicos são, na verdade, centros de poder ou força e toda ação é "ação à distância" entre esses centros de poder ou força. Tal como o Nachlass de Nietzsche torna evidente, sua concepção da "vontade de poder" incorpora essa ideia. ${ }^{19}$

Nietzsche usa este conceito para descrever as relações entre homens e mulheres no parágrafo 60 de $A$ gaia ciência: "A magia e o efeito mais poderoso das mulheres é, para usar a linguagem dos filósofos, a ação à distância, actio in distans" (FW/GC 60, KSA 3.425). Devemos ligar esta afirmação com o elogio de Nietzsche à definição de beleza em Stendhal como "promessa de felicidade". A beleza age à distância, como um objeto de percepção que promete algo além de si mesmo, como o signo de uma felicidade que parece estar escondida por trás desse signo - escondida para lá da percepção desse signo. A pulsão do amante para a posse é, por assim dizer, uma pulsão para entrar na vontade e no desejo do outro, uma pulsão para superar a resistência que o está impedindo de conquistar o que ele percebe como possível fonte de sua felicidade. $\mathrm{O}$ sentimento de poder resulta ou da superação ou da expectativa de superação dessa resistência.

19 Cf. Nachlass/FP 12 [27], KSA 10. 404; Nachlass/FP 34 [247] e 36 [31], KSA 11.503, 563: "os físicos não conseguem eliminar a 'ação à distância dos seus princípios, nem uma forma de repulsa (atração)". Cf. HESSE, Mary B. Forces and Fields, The Concept of Action at a Distance in the History of Physics. New York: Dover, 1962; POELLNER, Peter. Nietzsche and Metaphysics. Oxford: Oxford University Press, 2000, p. 48-57; GORI, Pietro. La Visione Dinamica del Mondo, Nietzsche e la filosofia naturale di Boscovich. Napoli: Edizioni La Città del Sole, 2007, p. 103 s.; BRANCO, Maria João Mayer. "Arte e Filosofia no Pensamento de Nietzsche", Diss., Lisbon: Faculdade de Ciências Sociais e Humanas, Universidade Nova de Lisboa, 2010, p. 258 s.; e BRANCO, Maria João Mayer ."Nietzsche on Metaphor, Musicality, and Style. From Language to the Life of the Drives". In. CONSTÂNCIO, J./ BRANCO, M.J.M. (eds.). Nietzsche On Instinct and Language. Berlin/Boston: De Gruyter, 2011, pp. 35-59.

$110 \mid$ Cad. Nietzsche, Guarulhos/Porto Seguro, v.37, n.1, p. 88-144, 2016. 
E isso significa superar a percepção de resistência.

Tentemos sistematizar agora a concepção de poder que está aqui pressuposta, e que Nietzsche tenta conceber nos termos da hipótese da "vontade de poder".

\section{"Poder" e "vontade de poder" em Nietzsche}

Embora, como mencionámos, Axel Honneth faça equivaler o conceito de poder em Nietzsche aos de Hobbes e Foucault, e afirme que a hipótese da vontade de poder em Nietzsche é incompatível com a ideia de reconhecimento, numa nota de rodapé do seu livro sobre o conceito de poder faz, apesar disso, uma importante observação: o conceito de poder em Nietzsche, ao contrário do de Foucault, assentou originalmente numa "doutrina das disposições" ${ }^{20}$, ou seja, numa doutrina dos afetos. E isso é realmente verdade. A "vontade de poder" é "um afeto" (Nachlass/FP 2 [151], KSA 12.140), um "pathos" (Nachlass/FP 14 [79], KSA 13.259), "a forma primitiva de afeto" (Nachlass/FP 14 [121], KSA 13.300), de modo que Nietzsche define sua morfologia da vontade de poder [Morphologie des Willens zur Macht] como uma morfologia dos afetos [Morphologie der Affecte]. ${ }^{21}$ Isto parece estabelecer imediatamente uma diferença importante em relação ao que podemos encontrar em Foucault. A filosofia de Nietzsche é uma "psicologia" (JGB/BM 23, KSA 5.39), considera a nossa "alma" (JGB/BM 12, KSA 5.27), a nossa vida subjetiva - a vida da psychē -, mesmo que seja uma psicologia que se entende a si própria como uma "doutrina dos afetos [Affektenlehre]" (Nachlass/ FP 13 [2], KSA 13.214) e, portanto, considere a nossa vida subjetiva a partir da perspectiva de como o corpo é afetado. Este é um fato

20 HONNETH, Axel. The Critique of Power, Reflective Stages in a Critical Social Theory. Transl. by Kenneth Baynes. Cambridge, Massachussets/ London, England: MIT Press, 1991, p. 322, nota 9. 21 Cf. NL 1886/87, KSA 12, 6[26] and NL 1888, KSA 13, 12[1]; NL 1888, KSA 13, 13[2]; NL 1888, KSA 13, 14[72] and NL 1888, KSA 13, 14[136]. 
Constâncio, J.

importante, e que é muitas vezes esquecido. Embora Nietzsche seja muito crítico do conceito de sujeito, e embora sua filosofia pressuponha claramente a possibilidade de perspectivas na terceira pessoa, não deixa por isso de se poder dizer que Nietzsche preserva ainda o conceito de subjetividade, pois que, como Schopenhauer, também Nietzsche faz filosofia "seguindo o fio condutor do corpo" [am Leitfaden des Leibes], isto é, seguindo o fio condutor da experiência subjetiva do corpo, a experiência do corpo na primeira pessoa a experiência psicológica de ser um corpo a partir de dentro. ${ }^{22}$ Assim, a questão é se a abordagem psicológica de Nietzsche - a sua filosofia como a psicologia, a sua "fisio-psicologia" como uma "morfologia e doutrina do desenvolvimento da vontade de poder" (JGB/BM 23, KSA 5.38) - implica um conceito de poder que seja fundamentalmente diferente tanto do de Hobbes quanto do de Foucault, bem como se a sua concepção de poder pode ser útil para obter uma descrição e compreensão do reconhecimento mútuo (em vez de ser inexoravelmente um conceito que se opõe à possibilidade de reconhecimento mútuo). Para que isso seja assim, o conceito de poder em Nietzsche terá de cumprir, pelo menos, duas condições: (a) não deve implicar que o poder seja uma função de uma pulsão egoísta para a preservação (como na concepção de Hobbes), (b) não pode

22 Cf. CONSTÂNCIO, João. "On Consciousness: Nietzsche's Departure from Schopenhauer”. In. Nietzsche-Studien 40, 2011, p. 1-42; CONSTÂNCIO, J./ BRANCO, M.J.M./ RYAN, B. Nietzsche and the Problem of Subjectivity (Org.). Berlin/ Boston: De Gruyter, 2015, sobretudo a Introdução; CONSTÂNCIO, J./ BRANCO, M.J.M./ RYAN, B. "Introduction to Nietzsche and the Problem of Subjectivity”. In. CONSTÂNCIO, J./ BRANCO, M.J.M./ RYAN, B. (Eds.). Nietzsche and the Problem of Subjectivity. Berlin/ Boston: De Gruyter, 2015 pp. 1-45; SOUSA, L. de/FAUSTINO, M. "Nietzsche and Schopenhauer on the 'Self' and the 'Subject"'. In. CONSTÂNCIO, J./ BRANCO, M.J.M./ RYAN, B. (Eds.). Nietzsche and the Problem of Subjectivity. Berlin/ Boston: De Gruyter, 2015, p. 131-165; RICCARDI, Mattia. "Nietzsche on the Embodiment of Mind and Self”. In: CONSTÂNCIO, J./ BRANCO, M.J.M./ RYAN, B. (Eds). Nietzsche and the Problem of Subjectivity. Berlin/ Boston: De Gruyter, 2015, p. 533-549. Sobre o filosofar "seguindo o fio condutor do corpo" [am Leitfaden des Leibes], cf. (Nachlass/FP 26 [374], 26 [432], 27 [27], KSA 11.249, 266, 282; Nachlass/FP 36 [35], 37 [4], 39 [13], 42 [3], KSA 11.565, 576, 623, 692; Nachlass/FP 2 [68], 2 [70], 2 [91], KSA 12.92, 106; Nachlass/FP 40 [21] [“Ausgangspunkt vom Leibe und der Physiologie"], KSA 11.638; Nachlass/FP 5[56], KSA 12205).

112 | Cad. Nietzsche, Guarulhos/Porto Seguro, v.37, n.1, p. 88-144, 2016. 
implicar que o poder seja o mesmo que a dominação - sobretudo, não pode implicar que "poder" signifique o mesmo que o controle social entendido como uma forma trans-subjetiva da dominação (como na concepção de Foucault). Meu argumento no que se segue é o de que mesmo um breve esboço do conceito de poder em Nietzsche mostra que este cumpre ambas as condições.

A hipótese da vontade de poder diz respeito, em primeiro lugar, às nossas pulsões [Triebe]. Ela presume que, na nossa experiência de nós mesmos, "não podemos descer ou subir acima de qualquer "realidade' que não seja a das nossas pulsões" (JGB/BM 36, KSA 5.54), e, portanto, ele postula (hipoteticamente) que aquilo que nos constitui é uma multiplicidade de pulsões. Estas pulsões percepcionam, interpretam, criam perspectivas umas sobre as outras e sobre si mesmas, bem como sobre o assim-chamado "mundo exterior" (uma ideia que já está presente em Aurora 119 e 129). Na medida em que cada pulsão é uma percepção elementar e uma perspectiva interpretativa, cada pulsão é, ao mesmo tempo, um "afeto". Ao percepcionar, uma pulsão é afetada por aquilo que ela percepciona e por como o percepciona. Isto permite a Nietzsche descrever o corpo como "uma sociedade construído a partir de muitas almas" (JGB/ $B M$ 19, KSA 5.33), isto é, de muitas pulsões e afetos que percebem, interpretam, formam perspectivas, e ao mesmo tempo permite-lhe preservar o conceito de "alma" como uma forma de descrever o corpo: a "alma" é "uma sociedade construída a partir de pulsões e afetos" (JGB/BM 12, KSA 5.27), ou seja, é um corpo inteligente (um "smart body", como se diz hoje) que percepciona, interpreta, forma perspectivas. No contexto da hipótese da vontade de poder, a concepção nietzschiana daquilo a que se chama tradicionalmente "alma" e "corpo" é "adualista" e, mais do que isso, envolve uma teoria de "duplo aspecto" sobre o corpo e a alma (ou seja, concebe o corpo e a alma como dois aspectos, ou duas descrições possíveis, 
Constâncio, J.

da mesma realidade). ${ }^{23}$

As pulsões e os afetos não são necessariamente conscientes, e na verdade apenas alguns de entre eles se tornam conscientes, assumindo então a forma de pensamentos, desejos e paixões (M/A 115, KSA 3.107; JGB/BM 36, KSA 5.54). Não só os desejos conscientes e as paixões, mas especialmente os pensamentos conscientes (que envolvem conceptualizações) são "apenas um determinado comportamento das pulsões umas em relação às outras" $(F W / G C 333$, KSA 3.559), ou são "apenas uma relação entre essas pulsões" (JGB/ $B M$ 36, KSA 5.54). Todas as formas de consciência propriamente humana são, em suma, apenas uma "superfície" e um "signo" de pulsões e afetos inconscientes (M/A 5, KSA 3.17; FW/GC 354, KSA 3.590; JGB/BM 19 e 32, KSA 5.31, 50; EH/EH, Por que sou tão Inteligente 9, KSA 6.294 ).

Deste modo, a subjetividade torna-se, para Nietzsche, uma subjetividade descentrada. Só se pode continuar a falar da "alma" se entende "alma" como "sujeito-multiplicidade" (JGB/BM 12, KSA 5.27). Que não haja "sujeito" não significa que não haja subjetividade (ou intersubjetividade): significa, sim, que não existe um centro fixo da nossa vida subjetiva, um "eu" ou "ego" consciente e imutável no centro da nossa experiência de nós mesmos na primeira pessoa

23 Sobre o "adualismo" de Nietzsche, cf. ABEL, Günter. "Bewußtsein-Sprache- Natur: Nietzsches Philosophie des Geistes", Nietzsche-Studien 30, Berlin, 2001, pp. 1-43; CONSTÂNCIO, João. "On Consciousness, op. cit.; sobre a sua teoria de "duplo aspecto", cf. STACK, George J. Lange and Nietzsche. Berlin: de gruyter, 1983; CONSTÂNCIO, João. "Towards a "Morphology of the Will to Power': Notes on Nietzsche's Conception of Philosophy as 'Psychology"'. In. MOLDER, M.F./ Soeiro, D./ Fonseca, N. (Eds.). Morphology: Questions on Method and Language. Bern/ Berlin/ Bruxelles/ Frankfurt a.M./ New York/ Oxford/ Wien: Peter Lang, 2013, p. 247-275; CONSTÂNCIO, J./ BRANCO, M.J.M./ RYAN, B. Nietzsche and the Problem of Subjectivity, op. cit; CONSTÂNCIO, J./ BRANCO, M.J.M./ RYAN, B. "Introduction to Nietzsche and the Problem of Subjectivity", op. cit.; GORI, Pietro. "Psychology without a soul, philosophy without and I. Nietzsche and 19th century Psychophysics (Fechner, Lange, Mach)". In. CONSTÂNCIO, J./ BRANCO, M.J.M./ RYAN, B. (Eds.). Nietzsche and the Problem of Subjectivity. Berlin/ Boston: De Gruyter, 2015, p. 166-195.

114 | Cad. Nietzsche, Guarulhos/Porto Seguro, v.37, n.1, p. 88-144, 2016. 
(e também em interação com outras pessoas, outros "sujeitos"). ${ }^{24}$ Somos uma multiplicidade de pulsões e afetos, um jogo de relações inconscientes entre "sub-almas" (JGB/BM 19, KSA 5.33), bem como de expressões conscientes, mas fragmentárias dessas relações. Partindo do princípio de que todos os elementos dessa multiplicidade competem e lutam uns com os outros, devemos conceber nossa subjetividade como sendo construída a partir de pulsões e afetos (ou de "sub-vontades ou sub-almas", JGB/BM 19, KSA 5.33) que são "vontades de poder": "O ser humano como uma multiplicidade de 'vontades de poder': cada uma com uma multiplicidade de meios de expressão e formas" (Nachlass/FP 1 [58], KSA 12.25).

Segundo a hipótese da vontade de poder, podemos dizer que uma pessoa é uma pessoa - ou que o seu ser tem unidade - apenas se pensarmos esta unidade como uma "organização e atividade conectada" entre uma multiplicidade de pulsões e afetos, ou seja, como "uma formação de supremacia que significa 'um', mas não é um" (Nachlass/FP 2 [87], KSA 12.104). Da mesma forma, podemos dizer que uma pessoa tem uma vontade ou mesmo que uma pessoa é uma vontade (por exemplo, uma "vontade forte" ou uma "vontade fraca"), mas apenas se entendermos essa "vontade" como o resultado (sempre provisório e não-substancial) da "organização e atividade conectada" das suas pulsões: por exemplo, uma "vontade forte" será o resultado de uma bem estabilizada - mas não incondicionalmente estável - "ordem hierárquica" [Rangordnung] entre as pulsões (ou seja, uma "formação de supremacia" construída em torno de uma "pulsão dominante"), uma "vontade fraca" será o resultado decadente de uma "anarquia dos instintos" etc.

Note-se que, se levarmos a sério a afirmação de Nietzsche de

24 Cf. CONSTÂNCIO, João. "Nietzsche on Decentered Subjectivity or, the Existential Crisis of the Modern Subject". In CONSTÂNCIO, J./ BRANCO, M.J.M./ RYAN, B. (eds.). Nietzsche and the Problem of Subjectivity. Berlin/ Boston: De Gruyter, 2015, p. 279-316.

Cad. Nietzsche, Guarulhos/Porto Seguro, v.37, n.1, p. 88-144, 2016. | 115 
que "a ação é tudo" e não há um "substrato neutro" por detrás das ações de uma pessoa (GM/GM, I, 13, KSA 5.279.), então a unidade de uma pessoa - a sua "vontade", a formação de supremacia que significa “um', mas não é um" - não existe como tal antes de ser expressa em ações (e, portanto, só pode ser conhecida retrospectivamente). ${ }^{\mathbf{2 5}}$

$\mathrm{O}$ conceito de poder em Nietzsche deve, antes de tudo, ser entendido do ponto de vista de toda esta concepção de nossa subjetividade em termos de uma multiplicidade de pulsões que lutam umas com as outras, mas que, nessa luta, também são capazes de se coordenar e estabelecer relações de organização hierárquica entre si. As pulsões são, de fato, "vontades de poder" ("as nossas pulsões podem ser reduzidas a vontade de poder": Nachlass/FP, 40 [61], p. KSA 11.661); cada pulsão procura poder para si própria, "cada pulsão anseia por dominação [ist herrsüchtig]" (JGB/BM 6, KSA 5.20); ou, como Nietzsche também diz: "Cada pulsão é uma espécie de desejo de dominação [Herrschsucht], cada uma tem a sua perspectiva, que ela gostaria de impor como norma a todas as outras pulsões"(Nachlass/ FP 7[60], KSA 12.315). Mas o poder de cada pulsão depende da sua relação com o poder das outras pulsões. O poder é relacional - só

25 Sobre este "expressivismo" de Nietzsche, cf. PIPPIN, Robert. Nietzsche, Psychology, \& First Philosophy. Chicago/ London: University of Chicago Press, 2010; PIPPIN, Robert. “The Expressivist Nietzsche". In. CONSTÂNCIO, J./ BRANCO, M.J.M./ RYAN, B. (Eds.). Nietzsche and the Problem of Subjectivity. Berlin/ Boston: De Gruyter, 2015, p. 654-667. Também para Hegel, “o que o sujeito é, é a série das suas ações” (PR §124, TWA 7, p. 233), e por isso nenhuma introspeção cartesiana pode revelar o sujeito — ou seja, o sujeito só pode ser conhecido retrospectivamente através das suas ações (cf. também, por exemplo, PR §343, p. 372 TWA 7, p. 504: “a história do espírito é a sua própria ação; pois o espírito é apenas aquilo que ele faz e a sua ação é fazer-se a si próprio"). Sobre o "expressivismo" de Hegel, cf. PIPPIN, Robert. Hegel's Practical Philosophy, op. cit. Sobre a crítica de Nietzsche à introspecção (ou "auto-observação"), cf. CONSTÂNCIO, João. "Towards a "Morphology of the Will to Power', op. cit.; CONSTÂNCIO, J./ BRANCO, M.J.M./ RYAN, B. "Introduction to Nietzsche and the Problem of Subjectivity", op. cit.; BRANCO, Maria João Mayer. "Questioning Introspection: Nietzsche and Wittgenstein on 'The Peculiar Grammar of the Word "I"'. In. CONSTÂNCIO, J./ BRANCO, M.J.M./ RYAN, B. (eds.). Nietzsche and the Problem of Subjectivity. Berlin/ Boston: De Gruyter, 2015, pp. 454-486.

$116 \mid$ Cad. Nietzsche, Guarulhos/Porto Seguro, v.37, n.1, p. 88-144, 2016. 
ocorre entre uma multiplicidade de vontades de poder.

Isto significa que, para que haja poder, tem de haver o tipo de realidade que percebe, interpreta, forma perspectivas, e este tipo de realidade tem de ser "atuante [wirkend]" (JGB/BM 36, KSA 5.55). "Poder" é o modo como vontades eficazes se relacionam com outras vontades eficazes; é uma função da "causalidade da vontade" (JGB/ $B M$ 36, KSA 5.55), ou seja, da forma como este tipo de causalidade opera entre uma multiplicidade de vontades que se relacionam umas com as outras. Se pensarmos isto ao nível macroscópico de "pessoas", ou seja, se pensarmos as relações interpessoais e sociais como relações entre vontades "sintéticas", o poder é o modo como as pessoas se afetam mutuamente umas às outras, o poder é o que acontece nas relações intersubjetivas (sendo cada "sujeito" apenas um "sujeito-multiplicidade"). Quando Nietzsche escreve que "tudo é vontade contra vontade [alles ist Wille gegen Willen]" (Nachlass/ FP 5 [9], KSA 12.187), quer dizer precisamente isto: desde as formas mais elementares de organização do nosso corpo até às formas mais complexas de relações interpessoais e sociais, só existem multiplicidades subjetivas e intersubjetivas cujos elementos se afetam uns aos outros. É por isso que a vontade de poder é um afeto ou pathos.

Na medida em que é um efeito de relações entre vontades, o poder é também relativo. Tal como Henning Ottmann escreveu, um "monopólio do poder [Machtmonopol]" é impossível: todo o poder é uma mistura de poder e falta de poder ou, por outras palavras, o poder é sempre uma questão de grau ${ }^{26}$. A vontade de poder é uma vontade de dominação (ou seja, a vontade de poder quer auctoritas, não apenas potentia e não apenas possibilitas), mas a dominação como dominação absoluta ou "posse" é impossível. Aquilo a que Honneth chama "a ideia reducionista de um domínio unilateral da força" em

26 OTTMANN, Henning. Philosophie und Politik bei Nietzsche, 2. verbesserte und erweiterte Auflage. Berlin/ New York: de gruyter, 1999, p. 5.

Cad. Nietzsche, Guarulhos/Porto Seguro, v.37, n.1, p. 88-144, 2016. | 117 
Constâncio, J.

Foucault ${ }^{27}$ não é sequer possível para Nietzsche. Ao nível das relações sociais, Nietzsche não descreve, de todo, o controle social como uma forma abrangente de dominação unilateral e trans-subjetiva, mas sim relações intersubjetivas que envolvem uma interação e mistura de domínio e vulnerabilidade. Um importante caso em questão é, obviamente, a versão nietzschiana da dialética do senhor e do escravo na Genealogia da Moral. O que Nietzsche descreve aqui é como o escravo é afetado pela opressão do senhor, e de tal forma que o ódio de sua impotência - seu ressentimento - acaba por criar novos valores (ou seja, uma nova postura intersubjetiva), de tal forma que, no final, esses valores afetam e derrotam o senhor por incutirem má consciência na sua relação intersubjetiva com o escravo.

A razão por que, segundo Nietzsche, o poder é relacional, intersubjetivo e relativo é que a resistência faz parte da essência do poder e da vontade de poder: "A vontade de poder só pode expressarse contra resistências" (Nachlass/FP 9 [151], KSA 12.424). A vontade de poder pressupõe uma multiplicidade de forças ou esferas de poder que resistem umas às outras. Até mesmo as relações mais assimétricas ou hierárquicas de poder pressupõem resistência e, na verdade, resistência recíproca: “dominar é suportar o contrapeso da força mais fraca, é, assim, uma forma de continuar a luta. Obedecer é igualmente uma luta: é a quantidade de força de resistência que permanece" (Nachlass/FP 26 [276], KSA 11.222).

Este conceito de poder como uma função da resistência recíproca também é crucial no modo como Nietzsche rejeita a interpretação da vontade de poder como uma pulsão egoísta de autopreservação. Nietzsche distingue claramente a vontade de poder de uma "vontade de existir" spinozista (cf. FW/GC 349, KSA 3.585; Nachlass/FP 34 [208], KSA 11.492), bem como de uma "luta pela existência" darwinista (cf. FW/GC 349, KSA 3.585; Nachlass/FP 34 [208], KSA 11.492) e de uma "vontade de viver" schopenhaueriana

27 HONNETH, Axel .The Critique of Power, op. cit., p. 175.

118 Cad. Nietzsche, Guarulhos/Porto Seguro, v.37, n.1, p. 88-144, 2016. 
(cf. $Z a / Z A$, Da autossuperação, KSA 4.147). A vontade de poder é uma vontade que quer sempre superar-se a si mesma, ir além de si mesma, crescer ou expandir o seu poder (cf. $F W / G C 349, \mathrm{KSA}$ 3.585). A hipótese da vontade de poder em Nietzsche implica uma teoria da ação que enfatiza o papel do risco e da estimativa de valor em lugar da prudência e da mera coerção - tal como a teoria da ação em Hegel. Consideremos a noção de risco em Nietzsche.

Dizer que uma vontade de poder quer crescer ou expandirse significa que ela quer superar-se a si mesma, e dizer que quer superar-se a si mesma significa que ela quer superar resistências. Por esta razão, uma vontade de poder busca sempre resistências que ela possa tentar superar e, portanto, põe-se frequentemente em risco, ou seja, arrisca e sacrifica a própria vida com vista a ter mais poder (ou seja, com vista a empoderar aquilo que ela valoriza):

Querer preservar a si mesmo é expressão de um estado indigente, de uma limitação do verdadeiro instinto fundamental da vida, que tende à expansão do poder e, neste querer, muitas vezes põe em risco e sacrifica a autopreservação. $\left(F W / G C\right.$ 349, KSA 3.585) ${ }^{28}$.

Uma das principais implicações desta ideia é que, se entendermos o conceito de pulsão egoísta de autopreservação como a concepção de uma pulsão homeostática que nos motiva a buscar sempre o prazer e evitar a dor (ou seja, se uma teoria da ação baseado na ideia de autopreservação implica o hedonismo), então

28 Cf. também $Z a / Z A$, Da autossuperação, KSA 4.147. Note-se que tudo o que estou tentando estabelecer é que a dinâmica da vontade de poder implica risco e, portanto, não é menos contrária à dinâmica da autopreservação do que a dinâmica hegeliana de uma luta por reconhecimento. No entanto, pode bem ser verdade que a concepção do risco em Hegel tenha outra implicação, que parece estar ausente na concepção de Nietzsche. Hegel sustenta que o fato de os seres humanos serem capazes de arriscar a vida por causa do reconhecimento coloca a espécie humana categorialmente à parte do reino animal (ou seja, arriscar morrer por causa do reconhecimento é uma forma de os seres humanos demonstrarem sua humanidade qua não-animalidade). Agradeço a Christoph Schuringa por me chamar a atenção para esta diferença entre Hegel e Nietzsche. 
a hipótese da vontade de poder é certamente uma hipótese que se opõe a tal conceito. Ao arriscar a procura de resistências que ela possa superar, a vontade de poder busca muitas vezes a dor por uma questão de autossuperação (cf. GM/GM, III, 28, KSA 5.411; Nachlass/FP 14 [174] KSA 13.360). Assim, o prazer é apenas um efeito colateral da conquista do poder, ou (mais precisamente) do sentimento de poder. $\mathrm{O}$ prazer não ocorre porque é o que buscamos como animais alegadamente impulsionados por uma pulsão egoísta de autopreservação, mas sim porque as nossas pulsões, enquanto vontades de poder, fazem-nos sentir um incremento de poder quando superam resistências dolorosas. É talvez útil citar apenas duas passagens típicas em que Nietzsche expressa estas ideias muito claramente:

O que é um prazer senão uma estimulação do sentimento de poder através de um obstáculo (mais fortemente ainda por obstáculos rítmicos e resistências) - levando-o a inchar? Assim, todo o prazer inclui dor. - Se o prazer se torna muito grande, a dor tem de ser muito longa e a tensão do arco prodigiosa (Nachlass/FP 35 [15], KSA 11.514).

A vontade de poder como vida - o ser humano não busca prazer e não evita o desprazer: compreende-se qual é o famoso preconceito que assim contradigo. Prazer e desprazer são meras consequências, meros fenômenos concomitantes - o que o ser humano quer, o que mesmo a menor parte de um organismo vivo quer é um incremento do poder. Aspirar a isso tem as duas consequências, prazer e desprazer; daquela vontade resulta que ele procure resistência, que ele precise de algo que se lhe oponha. $\mathrm{O}$ desprazer, como inibição de uma vontade de poder, é, portanto, um fato normal, o ingrediente normal de todo o acontecimento orgânico, e o ser humano não o evita, tem, pelo contrário, uma permanente necessidade dele: cada conquista, cada sentimento prazeroso, tudo o que acontece pressupõe a superação de uma resistência (Nachlass/FP 14 [174] KSA 13.360).

A ideia de que a vontade de poder é capaz de se pôr em risco a si mesma implica que uma vontade de poder seja movida 
por aquilo que ela valoriza e não por autopreservação. As pulsões, enquanto vontades de poder, são "avaliações", "estimativas de valor" (Werthschätzungen), uma pulsão difere de outra pulsão por dar valor a uma meta diferente daquela que é valorizada por outra pulsão (é por isso que, por exemplo, a pulsão de conhecimento e a pulsão sexual não são o mesmo). Dizer que a vontade de poder é capaz de arriscar a sua própria vida enquanto procura (dolorosas) resistências equivale a dizer que a sua luta por mais poder muitas vezes a leva a uma busca autodestrutiva, abnegada daquilo que ela valoriza. Mas, mais importante ainda, isso implica que uma pessoa, enquanto associação de pulsões coordenadas e hierarquizados, seja capaz de arriscar e até mesmo sacrificar a sua própria vida por causa daquilo que é valorizado pela sua "pulsão dominante". ${ }^{29}$

Sendo assim, a hipótese da vontade de poder não implica que todas as nossas ações sejam egoístas - o que implica é, pelo contrário, que os termos "egoísta" e "altruísta" são demasiado simples para poderem descrever adequadamente a natureza de nossas ações. Tendo em conta que uma pessoa é uma associação de pulsões, e tendo em conta que, como Nietzsche escreve em Humano, demasiado humano, o individuum é na realidade um "dividuum" (MA I/HH I 57, KSA 2.76), o que habitualmente se considera ser uma ação não-egoísta é, na realidade, uma ação que resulta do fato de que uma dada pessoa "ama algo de si mesma, uma ideia, um desejo, uma prole, mais do que uma outra coisa de si mesma, que ela divide assim a sua natureza e sacrifica uma parte de si mesma a outra parte de si mesma" (MA I/HH I 57, KSA 2.76). Por um lado, devemos dizer que essa ação não é realmente altruísta - pois ela é motivada pela necessidade de satisfazer a pulsão que valoriza a ideia, desejo ou prole em causa (ou

29 Tal como já foi sugerido en passant acima, Nietzsche defende que as pulsões de uma pessoa se organizam e coordenam sempre em torno de uma (mais ou menos estável) "pulsão dominante" ou "instinto dominante" (cf. GM/GM, II, 2, KSA 5.258; GM/GM, III, 8, KSA 3.351; WA/CW 8, KSA 6.29, Nachlass/FP 1 [61], KSA 12.26; Nachlass/FP 11 [322], KSA 13.135; Nachlass/FP, 23 [2], KSA 13.600. 
seja, a ação remete de volta para o agente). ${ }^{30}$ Mas, por outro lado, a ação também não é simplesmente egoísta - pois algo da pessoa (uma pulsão ou constelação de pulsões) é realmente sacrificada em nome da ideia, do desejo ou da prole que é valorizada pela pulsão dominante. Nietzsche não nega que o autossacrifício e o altruísmo sejam possíveis, pelo menos em algum grau. Numa nota póstuma de 1881, por exemplo, escreve que "nós vivemos numa cultura de altruísmo" e "por força do hábito pensa-se na existência do outro antes de pensar na nossa própria (por exemplo, o príncipe pensa primeiro na existência do povo, a mãe na do filho)" (Nachlass/FP 11 [199], KSA 9.521). Dito de outro modo, todas as ações humanas são, em certo sentido, autorreferidas e, portanto, "egoístas", mas (a) nenhuma ação humana é "egoísta" no sentido usual de ser motivada pelo autointeresse ou pela pulsão para a preservação de um ego fixo, estável e (b) a nossa subjetividade descentrada, dividida (o "dividuum" que somos) é muitas vezes organizada em torno de pulsões que valorizam as outras pessoas (ou até comunidades de pessoas) e que nos fazem agir para o bem de outras pessoas (ou mesmo para o bem de uma comunidade, de um país etc.). $\mathrm{O}$ ego do ego-ismo é, na melhor das hipóteses, um "conceito sintético" (JGB/BM 19, KSA 5.33) que emerge à mera superfície do nosso ser, e de fato, "a grande maioria das pessoas [...] nada fazem pelo seu ego ao longo da vida: o que eles fazem é feito pelo fantasma do seu ego, o qual se formou nas cabeças das outras pessoas em seu redor e lhes foi comunicado" (M/A 105, KSA 3.92). Por conta da plasticidade do nosso ser enquanto sujeitos descentrados (ou sujeitosmultiplicidades, dividua), somos propensos a valorizar outras pessoas, bem como metas que compartilhamos com elas e tentamos alcançar em cooperação com elas, de modo que somos, na verdade, propensos a desenvolver identidades (identidades não-fixas e instáveis) que

30 Cf., por exemplo, MA I/HH I 133, 138, KSA 2.126, 131; M/A 105, KSA 3.92; FW/GC 13, KSA 3.384.

122 | Cad. Nietzsche, Guarulhos/Porto Seguro, v.37, n.1, p. 88-144, 2016. 
são co-determinadas pela forma como somos afetados e alterados por outras pessoas. (A tarefa de criar um verdadeiro "ego" parece ser uma tarefa para as exceções, para os "tipos mais elevados" ou "indivíduos soberanos".). $)^{31}$

Como podemos ver, a hipótese nietzschiana de que todas as relações sociais e interpessoais sejam relações de poder implica a rejeição de toda e qualquer possível versão da concepção hobbesiana da sociedade como uma coleção de vontades estáveis e individuais que procuram a sua própria preservação e prazer, bem como de qualquer doutrina que assuma que a cooperação entre indivíduos tem necessariamente de ser motivada pelo medo, pela prudência, pela cautela ou por algum outro afeto egoísta semelhante a esses. Segundo Nietzsche, vontades individuais (ou de pessoas enquanto unidades sintéticas de multiplicidades de vontades de poder) são vontades divididas, plásticas e sempre já sociais que querem autossuperação, não prazer e autopreservação, e, portanto, vontades que facilmente se tornam parte de esferas coletivas de poder, facilmente cooperam com outras vontades, e facilmente se identificam com interesses coletivos de formas que as levam a arriscar o seu prazer e existência individuais em nome daquilo valorizam num determinado momento do tempo. O melhor exemplo disso é a verdadeira amizade como "uma espécie de continuação do amor, na qual a cobiçosa ânsia que duas pessoas têm uma pela outra deu lugar a um novo desejo e cobiça, a uma elevada sede conjunta de um ideal acima delas" (FW/GC 14, KSA 3.387).

Isso não quer dizer que seja impossível que uma pulsão de autopreservação alguma vez se torne a "pulsão dominante" num indivíduo, nem Nietzsche nega que, em algumas circunstâncias, uma comunidade de seres humanos possa ser inteiramente constituída por indivíduos que simplesmente lutem pela autopreservação e

31 Cf. GEMES, Ken. "Nietzsche on Free Will, Autonomy and the Sovereign Individual”. In. Aristotelian Society Supplementary, Volume, 80, 2006, p. 321-338.

Cad. Nietzsche, Guarulhos/Porto Seguro, v.37, n.1, p. 88-144, 2016. 
Constâncio, J.

sobrevivência. Mas, como se disse acima, a sua tese é a de que "a luta pela sobrevivência é apenas uma exceção, uma restrição temporária da vontade da vida" (FW/GC 349, KSA 3.585). O melhor exemplo de uma tal exceção é, talvez, a vida dos prisioneiros num campo de concentração tal como é descrita por Primo Levi no seu livro, Se isto é um homem. Mas em qualquer forma normal de vida social - onde existem laços familiares, valores comuns, direitos e deveres recíprocos e níveis mínimas de segurança, de saúde e nutrição - ninguém vive realmente dominado por uma pulsão de autopreservação.

Pode, é claro, argumentar-se que numa luta pela autopreservação o que vem à tona é o nosso "instinto animal" (GM/GM, II, 22, KSA 5.332), os "velhos instintos" do caçador-coletor e "todos aqueles instintos do ser humano selvagem, livre, nómade" (GM/GM, II, 16, KSA 5.322). Com efeito, deve ficar claro que a hipótese da vontade de poder inclui a ideia de que estas "pulsões malvadas" e "afetos de ódio, inveja, ganância e luxúria" são "os afetos condicionantes da vida", que estes não podem deixar de estar presentes "na economia total da vida" e, consequentemente, "têm de ser incrementados, caso a vida deva ser incrementada" (JGB/BM 23, KSA 5.38). Mas a hipótese da vontade de poder não reduz nossa psicologia a esses afetos e pulsões agressivas, malvadas, nem as concebe como uma espécie de cerne último do nosso ser, a nossa "verdadeira" natureza escondida. Pois, na verdade, essa é uma hipótese sobre o desenvolvimento $(J G B / B M$ 23, KSA 5.38) desses afetos e pulsões; sobre como, por exemplo, "tudo o que chamamos de 'alta cultura' se baseia na espiritualização e aprofundamento de crueldade" (JGB/BM 229, KSA 5.166); e sobre como os seres humanos se tornam seres plurais e complexos, de tal forma que cada um é de fato uma "multiplicidade de vontades de poder" (Nachlass/FP 1 [58], KSA 12.25) e a alma moderna há muito se tornou "uma pilha de contradições" (Nachlass/FP 9 [183], KSA 12.446).

Este tipo de "desenvolvimento" (por exemplo, como "espiritualização e aprofundamento") consiste, em parte, no

$124 \mid$ Cad. Nietzsche, Guarulhos/Porto Seguro, v.37, n.1, p. 88-144, 2016. 
Lutas por reconhecimento e vontade de poder: ...

desenvolvimento de novos costumes, normas, direitos e deveres na vida social. E estas são formas de valorização que envolvem interações simbolicamente mediadas à "superfície" da consciência. Os valores instintivos, inconscientes de nossas pulsões desempenham um papel crucial na definição do tipo de relações de poder que estão na base de todas as relações interpessoais e da vida social, mas o "mundo de superfície e signos" (FW/GC 354, KSA 3.590) da consciência - em particular da consciência de costumes, normas, direitos e deveres também desempenha um papel crucial. Para Nietzsche, a consciência é a superfície que surge da nossa capacidade de formular conceitos e palavras, pois conceitos e palavras (segundo este ponto de vista) expressam relações subterrâneas entre as pulsões, e depois também causam alterações nessas relações subterrâneas. O que é ainda mais importante, Nietzsche pensa que os conceitos e as palavras (ou a consciência e a linguagem) não pertencem à "existência do ser humano como indivíduo, mas sim aos aspectos comunitários e gregários de sua natureza" ( $F W / G C$ 354, KSA 3.590). A consciência (em conjunto com a linguagem) é a "rede de conexão" que permite que os seres humanos formem comunidades comunicando uns com os outros com base em símbolos ou "signos de comunicação" ( $F W /$ GC 354, KSA 3.590). Costumes, normas, direitos e deveres são, naturalmente, uma parte crucial de uma tal "rede". Portanto, estas avaliações que envolvem interações simbolicamente mediadas são de fato tão importantes para a própria existência da sociedade como aquelas outras avaliações pré-simbólicas e pré-conceituais.

No entanto, mesmo as relações de poder pré-simbólicas e pré-conceituais são, em certo sentido, mediadas. Pois, segundo Nietzsche, todas as relações de poder pressupõem distância: "ação à distância". Para que haja vontade de poder, uma vontade tem de ser capaz de afetar uma outra vontade à distância, como a Terra parece afetar a lua (enquanto também é afetada pela lua) sem contato físico ou impacto. Uma multiplicidade de vontades de poder é uma multiplicidade de vontades atuando à distância e sendo atuadas 
(ou sendo afetadas por) outras vontades também à distância. É por isso que todas as relações de poder dependem de percepções, perspectivas e interpretações - mesmo que estas ocorram apenas ao nível inconsciente (ou puramente afetivo) das pulsões e dos instintos. As relações de poder assimétricas (por exemplo, entre senhor e escravo) resultam, muitas vezes, de violência e coerção, mas mesmo nesses casos a relação de poder depende da ameaça de novos atos de violência e, portanto, da percepção do poder e da estimativa de uma quantidade superior de poder. Além disso, uma vontade pode exercer poder sobre outra vontade sem qualquer tipo de violência ou coerção, como vimos no caso do amor sexual: "A magia e o efeito mais poderoso das mulheres é, para usar a linguagem dos filósofos, a ação à distância, actio in distans" (FW/GC 60, KSA 3.425).

É por isso que Nietzsche afirma que a vontade de poder é um "pathos" ou um "afeto", isto é, um ser-afetado pela percepção de resistência e, assim, um ser-afetado à distância. Mesmo na relação entre um senhor e um escravo, a vontade do escravo nunca é em absoluto propriedade do senhor: enquanto a relação de poder perdura, a vontade do escravo, ou sua "vontade de poder", continua a resistir ao senhor, ou à sua "vontade de poder", "à distância". A eliminação da resistência e da percepção (ou reconhecimento) de resistência à distância eliminaria a própria relação de poder. Portanto, a posse absoluta é impossível e a dominação é um paradoxo, pois quanto menos resistência existir, menos existirá de que se possa tomar posse e dominar ${ }^{32}$.

Deste modo, ao afirmar que todas as relações sociais são relações de poder, o que Nietzsche pretende dizer é que todas as

32 O parágrafo 93 de Humano, demasiado humano dá um excelente exemplo deste paradoxo. Se uma cidade sitiada for completamente destruída, os conquistadores não poderão exercer poder sobre a cidade. Para exercerem poder, precisam de uma força que se lhes oponha e sobre a qual possam, então, exercer poder. E uma vez que a cidade sitiada é capaz de ameaçar com a autodestruição, ainda tem esta última ameaça como fonte de resistência e, por conseguinte, de poder. Este mínimo de resistência e de poder é suficiente para forçar um processo de equalização, um processo do qual resulta um certo equilíbrio (MA I/HH I 92, KSA 2.89)

$126 \mid$ Cad. Nietzsche, Guarulhos/Porto Seguro, v.37, n.1, p. 88-144, 2016. 
relações sociais dependem de um dado "equilíbrio" (WS/AS 22, KSA $2.555)$ de "graus de poder reconhecidos e garantidos" (M/A 112, KSA 3.101). Não é o poder como força bruta que mantém uma sociedade unida, mas sim uma multiplicidade de interações simbolicamente mediadas nas quais ocorre o reconhecimento mútuo de diferentes graus de poder. Já ao nível das relações puramente interpessoais, um mínimo de reconhecimento de uma outra vontade como outra vontade faz parte de toda a relação de poder, até mesmo das relações de poder mais assimétricas, anisotrópicas. Para o dizer nos termos da relação senhor/escravo: o senhor não considera o escravo como pessoa, não se relaciona com o escravo, de todo em todo, como um igual, mas ainda assim sente, pelo menos, um mínimo de resistência da parte do escravo, isto é, reconhece um mínimo de poder no escravo. E o escravo, é claro, sente-se forçado a resignar-se a ser subjugado pelo senhor porque estima que as outras opções são piores do que ser subjugado pelo senhor e, portanto, reconhece o poder superior da posição do senhor.

Tais relações interpessoais como a que existe entre o senhor e o escravo estão, no entanto, sempre já incorporadas em redes maiores de relações de poder simbolicamente mediadas, ou seja, numa sociedade que consiste em tais relações. Como Volker Gerhardt mostrou, a teoria da sociedade de Nietzsche inclui até o argumento de que, uma vez que as relações de poder são mediadas por percepções, perspectivas, interpretações, conceptualizações, signos de comunicação, normas, direitos, deveres etc., o equilíbrio de poder numa sociedade depende sempre de algum tipo de "compreensão simbólica" ou "acordo" entre os seus membros, ${ }^{33}$ ou seja, um "contrato" (MA I/HH I 446, KSA 2.90)

33 (Cf. GERHARDT, Volker. "Das 'Prinzip des Gleichgewichts'. Zum Verhältnis von Recht und Macht bei Nietzsche”. In. GERHARDT, V. Pathos und Distanz. Studien zur Philosophie Friedrich Nietzsches. Stuttgart: Reclam, 1988, p104). A idéia de HH I 446, KSA 2.290, é: "Ohne Vertrag kein Recht" [sem pacto, não há direito]. Esta ideia não é contraditória com a tese ulterior (em Além do bem e do mal e Genealogia da Moral) de que o início da sociedade não se dá por contrato, mas sim por atos de violência. 
Constâncio, J.

estabelecido com base num recíproco reconhecimento de poder. ${ }^{\mathbf{3 4}}$

Prima facie, o conceito de "reconhecimento" recíproco de diferentes graus de poder no quadro de um dado equilíbrio de poder parece ser algo totalmente diferente do reconhecimento recíproco hegeliano como reconhecimento de si "no outro", especialmente dado que esta última forma de reconhecimento envolve uma mudança no estatuto atribuído ao outro - uma mudança em resultado da qual o outro deixa de ser um obstáculo à sua liberdade e passa a ser uma condição de liberdade. Mas esta diferença torna-se relativa uma vez que se considere que o reconhecimento recíproco de diferentes graus de poder no quadro de um equilíbrio de poder pode ser entendido como uma descrição alternativa do reconhecimento de si "no outro", porque, como acabamos de ver, se refere a um equilíbrio intersubjetivo de poder - com a diferença apenas de que as "pessoas" são agora aqui redescritas como "vontades", "esferas de poder", "sujeitosmultiplicidades" constituídos a partir de pulsões que são "vontades de poder" etc. (A questão levantada neste artigo é precisamente a de saber quão frutífera esta redescrição pode ser.) Além disso, essa objeção só seria válida se a concepção de Nietzsche só reconhecesse relações de poder assimétricas - mas isso não é de todo o caso. Ele defende, sim, que existem relações de poder simétricas, equilíbrios de poder em que as partes envolvidas se reconhecem umas às outras

34 Isto não impede Nietzsche de ser crítico da concepção liberal do contrato social, tal como Hegel também o é: cf. JGB/BM 257, KSA 5.205; GM/GM, II, 17, KSA 5.324. Note-se que, até certo ponto, as razões de um e do outro para rejeitarem essa concepção são muito similares: ambos rejeitam a noção liberal de sujeitos associais, i.e. de indivíduos já constituídos como indivíduos antes de haver sociedade. Cf. OWEN, David. Nietzsche, Politics and Modernity. London: Sage, 1995; OWEN, David "Nietzsche, Ethical Agency and the Problem of Democracy". In. SIEMENS, H./ ROODT, V. (Eds.). Nietzsche, Power and Politics. Berlin/ New York: de gruyter, 2008, p. 143-167; SIEMENS, Herman. "Nietzsche's socio-physiology of the self". In. CONSTÂNCIO, J./ BRANCO, M.J.M./ RYAN, B. (Eds.). Nietzsche and the Problem of Subjectivity. Berlin/ Boston: De Gruyter, 2015, p. 629-653.

128 Cad. Nietzsche, Guarulhos/Porto Seguro, v.37, n.1, p. 88-144, 2016. 
como iguais, isto é, em que uma vontade reconhece outra vontade como igualmente poderosa e, portanto, uma pessoa reconhece outra pessoa como um igual, ou como uma pessoa com um grau de poder e um estatuto mais ou menos igual (cf., por exemplo, JGB/BM 259, 260, KSA 5.207, 208; GM/GM, I, 10, II, 2, KSA 5.270, 293). Assim, tal como Hegel descreve as formas mais elementares e mais bárbaras de reconhecimento recíproco como instâncias de não-reconhecimento - ou de reconhecimento-malogrado - e as formas mais completas e perfeitas de reconhecimento como desenvolvimentos de tais formas elementares e bárbaras, assim também Nietzsche descreve relações assimétricas e simétricas de reconhecimento de poder de uma forma que nos faz questionar se todos os desenvolvimentos e transições de reconhecimentos-malogrados e desigualdades para formas de reconhecimento e igualdade poderiam e deveriam ser redescritas como desenvolvimentos e transições de relações de poder assimétricas para relações de poder simétricas.

Na seção seguinte, irei resumir toda esta interpretação do conceito de poder em Nietzsche de forma a tornar explícita a sua ligação com a concepção de lutas por reconhecimento em Hegel. Além disso, descreverei brevemente possíveis continuações e desenvolvimentos desta pesquisa sobre poder e reconhecimento.

\section{Vontade de poder e reconhecimento}

Nietzsche não entende o poder nem no sentido pejorativo de um controle com base na violência, nem no sentido pejorativo de um controle com base em fraude. Além disso, a definição des-subjetivada de poder que Honneth acredita poder atribuir não só a Foucault, mas também a Nietzsche - ou seja, "o sucesso numa situação de luta"35 - também não explica o fato de Nietzsche ver o poder como o poder de uma "vontade" sobre uma outra "vontade". Para Nietzsche, "a

35 HONNETH, Axel. The Critique of Power, op. cit., p. 196-98. 
questão" é "se nós acreditamos na causalidade da vontade" e se "essa crença é realmente apenas a nossa crença na própria causalidade" (JGB/BM 36, KSA 5.55). Isso fá-lo desenvolver uma concepção intersubjetiva de poder (embora cada "vontade" seja sempre já uma síntese de uma multiplicidade de sub-vontades ou pulsões, cada unidade de "vontade" deve ser vista apenas como uma coordenação entre "sub-vontades", a qual se forma no próprio momento em que cada ação é praticada, e nunca antes ou independentemente da ação). Por isso, não só a sua concepção de poder envolve uma "diversidade de relações de poder" e uma "multiplicidade de sujeitos que competem entre si" - em lugar de haver um só sujeito com todo o poder ${ }^{\mathbf{3 6}}$, como também não implica um modelo "trans-subjetivo" de relações de poder, ou seja, Nietzsche nunca deixa de defender que as relações sociais e interpessoais sejam basicamente relações de poder intersubjetivas, isto é, relações de poder baseadas em percepções, perspectivas e interpretações recíprocas. Além disso, estas relações são, para Nietzsche, simbolicamente mediadas, e muitas vezes são relações de cooperação entre iguais - o que também diferencia a concepção nietzschiana de relações de poder da de Foucault.

Assim sendo, podemos definir "poder" [Macht] como influência de uma "vontade" sobre uma outra "vontade", ou seja, como influência intersubjetiva. Na medida em que o poder emerge sempre de uma interação de "vontade contra vontade", e neste jogo cada vontade "quer" dominação, o poder nunca é apenas uma questão de possibilidade (possibilitas) e capacidade (potentia), mas também de dominação (auctoritas). Ou, dito de outro modo, influência intersubjetiva implica sempre um determinado grau de autoridade de uma vontade sobre outra vontade. Como observa Kojève, "autoridade é necessariamente uma autoridade reconhecida"37 ou, na linguagem de Nietzsche, a autoridade é "ação à distância", pois as relações de

36 Cf. Id. Ibdem, p.155

37 KOJÈVE, Alexandre. The Notion of Authority, op. cit., p 8.

$130 \mid$ Cad. Nietzsche, Guarulhos/Porto Seguro, v.37, n.1, p. 88-144, 2016. 
autoridade são "relações de supremacia [Herrschaftsverhältnisse]" (JGB/BM 19, KSA 5.34), ou seja, relações de comando e obediência. E estas têm, necessariamente, como base uma consciência recíproca, ou seja, percepções recíprocas, perspectivas recíprocas, interpretações recíprocas. Segundo Kojève, "autoridade é a possibilidade que um agente tem de atuar sobre outros (ou sobre um outro), sem que esses outros reajam contra ele, apesar de poderem fazê-lo"38. Um agente A tem autoridade sobre outro agente $B$ se $A$ não precisa usar a força ou a violência para levar $\mathrm{B}$ a fazer $\mathrm{X}$ e se a consciência que $\mathrm{B}$ tem de ser comandado por $\mathrm{A}$ a fazer $\mathrm{X}$ não o leva a reagir contra fazer $X$. Nietzsche, segundo creio, concordaria - mas não inteiramente. Pois, segundo Nietzsche, mesmo que, estritamente falando, B "não reaja contra" fazer $\mathrm{X}$, ainda assim e na medida em que B é uma "vontade", pode oferecer resistência a A, estabelecendo, com isso, um limite à autoafirmação e supremacia de A.

Este é um ponto crucial não só porque implica que a dominação nunca é absoluta, mas também porque explica por que razão a dominação contém sempre em si mesma as sementes da sua autossabotagem e autossubversão. Vimos isso na seção II com o exemplo do amor sexual. Nas histórias dos três amantes $(J G B / B M$ 194, 5.15), a resistência oferecida pela mulher amada mostra, em primeiro lugar, que a posse é impossível e, em segundo lugar, mostra como a vontade de dominar pode ser gradualmente posta em causa ou sabotada por essa resistência e acabar por ser subvertida em algum tipo da igualdade entre o homem e a mulher, isto é, numa relação de poder simétrica e entre iguais. Portanto, aqui uma relação de reconhecimento-malogrado conduz, finalmente, numa série de etapas e fases, a algo pelo menos semelhante a um estado de "reconciliação" ou reconhecimento recíproco. Mas vimos também como a plasticidade social do nosso "si" [Selbst] o torna propenso à cooperação, isto é, como a resistência recíproca e a vulnerabilidade entre seres

38 Id. Ibdem, p. 8.

Cad. Nietzsche, Guarulhos/Porto Seguro, v.37, n.1, p. 88-144, 2016. 
Constâncio, J.

humanos faz com que seja fácil a identificação com metas conjuntas ou coletivas, bem como a cooperação (e até uma quasi-fusão) na prossecução de tais metas. Um dos exemplos que consideramos foi como o amor sexual entre duas pessoas se torna uma amizade cooperativa quando é transformado em "um novo desejo e cobiça, uma elevada sede conjunta de um ideal acima delas" (FW/GC 14, KSA 3.387). Aqui, mais uma vez, o que a princípio era apenas vulnerabilidade recíproca e reconhecimento-malogrado leva, por fim, à reconciliação (o "eu” torna-se um "nós”).

Porém, comparemos finalmente estas conclusões com o que vimos sobre as lutas por reconhecimento em Hegel:

(i) Tanto na concepção de lutas por reconhecimento em Hegel quanto na concepção de vontade de poder em Nietzsche, é identificada uma dinâmica de interação interpessoal e social que implica riscos e, por isso, quebra com o modelo usual da interação motivada por uma pulsão de autopreservação.

(ii) As duas concepções pressupõem um espaço intersubjetivo de interação, na verdade de autoafirmação e vontade recíproca de dominar. Note que isto não é uma questão de necessidade unilateral de aprovação. Em Hegel, as lutas por reconhecimento são sempre recíprocas, isto é, verdadeiramente intersubjetivas: a luta pelo reconhecimento só ocorre quando ambos os lados lutam para ver o seu valor e o seu próprio sentimento de si reconhecidos. Em Nietzsche, o caso de amor sexual também mostrou como tais lutas recíprocas e recognitivas de afirmação podem ser concebidas em termos de "vontade de poder"39.

(iii) Tanto na concepção de lutas por reconhecimento em Hegel quanto na concepção de vontade de poder em Nietzsche, pressupõe-

39 Veja-se, de novo, a crítica de Robert R. Williams à má interpretação que Deleuze faz do pensamento de Hegel neste ponto decisivo: WILLIAMS, Robert R. Tragedy, Recognition, op. cit., p.: 39). Sobre o reconhecimento entendido como mera (aspiração a) aprovação unilateral e a sua crítica em Nietzsche como comportamento típico de naturezas gregárias, veja-se, por exemplo, JGB/BM 206, KSA 5.133.

132 | Cad. Nietzsche, Guarulhos/Porto Seguro, v.37, n.1, p. 88-144, 2016. 
se e exprime-se (embora de maneiras diferentes) a tese de que o ser humano é sempre já social. Com efeito, ambos os autores enfatizam a plasticidade da individualidade humana. (O que Nietzsche rejeita é a convicção de Hegel de que a "racionalidade" é o critério básico para distinguir identificações de um "eu" com um "nós" mais paroquial de outras mais universais).

(iv) Ambas as concepções implicam, também, que os processos de autoafirmação recíproca enredam os agentes neles envolvidos na tarefa impossível de coagir reconhecimento. $\mathrm{O}$ que sublinhei na seção I foi que, segundo Hegel, enquanto dura uma luta pelo reconhecimento, há sempre um elemento de poder (ou força) embora não necessariamente de violência direta, física - na interação intersubjetiva que está a ter lugar. No duelo de vida ou morte primordial e em todas as lutas que, fundamentalmente, repetem o seu padrão, as partes envolvidas usam diretamente a violência para tentar coagir o reconhecimento do outro. A sua vontade de autoafirmação torna-se uma vontade de dominar o outro - uma vontade de encontrar "satisfação noutra autoconsciência" por meio de coerção. Aqui, os sujeitos ou agentes comportam-se uns em relação aos outros da mesma forma como cada consciência desejante se comporta em relação a uma coisa, ou seja, com um desejo de dominação, um desejo de consumir, possuir, assimilar o outro (ou seja, cada sujeito se relaciona com o outro como se este fosse um objeto.) Apenas uma Freigabe, apenas uma renúncia à vontade de dominar o outro, pode transformar o reconhecimento-malogrado num genuíno reconhecimento recíproco. Ao conceber uma dinâmica de vontade intersubjetiva de dominar (ou "vontade de poder"), também Nietzsche descreve a dinâmica do reconhecimento-malogrado como uma dinâmica em que pelo menos uma das partes envolvidas tenta coagir reconhecimento. A sua análise do amor mostra que também ele acredita que somente algum tipo de Freigabe pode levar ao reconhecimento mútuo. 
Constâncio, J.

(v) O que isto significa é que a concepção de lutas por reconhecimento em Hegel e a concepção de vontade de poder em Nietzsche implicam ambas aquilo a que chamei "o paradoxo da dominação". ${ }^{40}$ A base deste paradoxo é o fato de que é impossível coagir reconhecimento. Este fato significa que nunca é possível a estabilização absoluta de uma relação de dominação porque, enquanto a parte dominada permanece viva e é ainda um sujeito (ou seja, uma autoconsciência, mesmo que apenas uma "consciência de si dependente"), a relação de dominação contém em si as sementes da sua própria autossabotagem e autossubversão. Ou, nos termos de Nietzsche, na medida em que a parte dominada é uma "vontade de poder", ela não pode deixar de resistir a ser dominada pela outra parte, e isso garante que a interação entre ambas as partes tem sempre em si as sementes da sua própria autossubversão. $\mathrm{O}$ paradoxo ele próprio é que, sendo assim, quanto mais um sujeito consegue dominar outro sujeito, menos consegue dominá-lo enquanto sujeito. Pois se o outro sujeito for dominado e, portanto, "reificado", tratado como uma "coisa", como um "escravo" privado de uma vontade independente, torna-se menos "sujeito". 41 A forma como Nietzsche analisa o amor sexual em Além do Bem e do Mal é, de novo, um excelente exemplo deste paradoxo.

(vi) Por fim, ambas as concepções tentam explicar não só como funciona o reconhecimento-malogrado, mas também como e por que o reconhecimento-malogrado pode passar por processos de autossabotagem e autossubversão e transformar-se em reconhecimento recíproco e bem-sucedido (i.e., em reconciliação). Tal como foi

40 Uma das inspirações deste artigo foi o trabalho de Robert B. Pippin sobre aquilo a que ele chama "the paradoxes of power": cf. "The Paradoxes of Power in the Early Novels of J.M. Coetzee". In. Leist, A./ Singer, P. (Eds.). J.M. Cotzee and Ethics. New York: Columbia, 2010, p. 19-41.

41 Cf. BENJAMIN, Jessica. "Senhor and Escravo: The Bonds of Love”. In. O’NEILL, J. (Org.). Hegel's Dialectic of Desire and Recognition. New York: SUNY, 1996, p. 209): "if I completely control the other, then the other ceases to exist, and if the other completely controls me, then I cease to exist."

$134 \mid$ Cad. Nietzsche, Guarulhos/Porto Seguro, v.37, n.1, p. 88-144, 2016. 
mencionado desde o início, este último ponto é, no entanto, aquele em que Hegel e Nietzsche também diferem mais substancialmente. Para Hegel, a Freigabe que torna possível a reconciliação consiste no reconhecimento recíproco de racionalidade. Nietzsche concorda que a comunicação inteligente, a mediação simbólica, talvez até mesmo o acordo e o compromisso (que parecem envolver a razão) são cruciais para o reconhecimento recíproco entre iguais. Mas, para ele, a transição do reconhecimento-malogrado para o reconhecimento recíproco é uma transição de uma relação de poder assimétrica para uma relação de poder simétrica em que o reconhecimento recíproco de racionalidade não parece desempenhar um papel crucial - pelo menos, não num sentido hegeliano, i.e., no sentido de a outra pessoa deixar de ser uma limitação para a minha liberdade e passar a ser uma condição da minha liberdade porque a reconheço como um sujeito racional e ela me reconhece como outro sujeito racional etc.

Mesmo assim, os principais pontos que tentei transmitir neste artigo parecem-me suficientes para se estabelecer que há uma profunda afinidade entre a concepção hegeliana de lutas por reconhecimento e a hipótese da vontade de poder em Nietzsche. Se isso for verdade, então há toda uma panóplia de temas nietzschianos que precisam ser revistos à luz de tal afinidade:

(i) O caso mais óbvio é a "dialética" nietzschiana do senhor e do escravo em Além de bem e mal (JGB/BM 46, 62, 195, 199, 260, KSA 5.66, 81, 116, 119, 208) e, especialmente, na Genealogia da Moral (GM/GM I e passim, KSA 5.257 s.). Uma comparação completa entre Hegel e Nietzsche a respeito da relação senhor/escravo é algo que não foi ainda tentado. Tal deve incluir uma consideração da sugestão de Robert B. Pippin de que a Genealogia da Moral deve ser lida como algo semelhante à "Fenomenologia [do Espírito], Segunda Parte" ${ }^{\text {"2 }}$.

42 Cf. PIPPIN, Robert B. Hegel's Practical Philosophy, op. cit., p. 280-81; WILLIAMS, Robert R. Tragedy, Recognition, and the Death of God, op. cit. 
Constâncio, J.

(ii) A concepção de agon em Nietzsche deve ser revista à luz da ideia de que a sua concepção de poder implica compreender a dominação como algo que, potencialmente, se autossabota e se autossubverte. Esta ideia parece-me ser particularmente interessante para a reinterpretação do conceito do tipo "nobre" e das comunidades aristocráticas em Nietzsche, assim como de outros tipos de relações entre iguais. Do "indivíduo soberano", por exemplo, Nietzsche diz que faz parte de sua natureza sentir sempre "reverência", "respeito" [Ehrfurcht] pelos seus "iguais" (GM/GM, II, 2, KSA 5.295), e até mesmo dos nobres do primeiro ensaio da Genealogia, Nietzsche diz que quando são inimigos uns dos outros a sua inimizade recíproca é “já uma ponte para o amor” (GM/GM, I, 10, KSA 5.273).

(iii) Em termos mais gerais, a possibilidade de haver uma "profunda afinidade" entre Nietzsche e Hegel no que respeita às suas concepções de intersubjetividade e reconhecimento (e, especialmente, no que respeita às dinâmicas intersubjetivas de desejo, luta, conflito e dominação, ou seja, de reconhecimentomalogrado) apela a uma reinterpretação do modo como Nietzsche pensa a sociedade, o estado de natureza, o contrato social etc. Neste quadro, são particularmente importantes a tese de Humano, demasiado humano de que as sociedades humanas são basicamente uma multiplicidade de equilíbrios de poder (WS/AS 22, KSA 2.555) e, em Aurora, a concepção de direitos e deveres como "graus de poder reconhecido" (M/A 112, KSA 3.100). Igualmente importantes são os seus pontos de vista da maturidade sobre o instinto de "rebanho" e sobre como os indivíduos são "disciplinados e cultivados" por valores e normas que promovem o interesse do "rebanho" (ou seja, da comunidade, da sociedade etc.) e não do indivíduo. Se a minha interpretação da vontade de poder é correta, então esta "disciplina e cultivo [Zucht und Züchtung]" é ainda intersubjetiva e não (como as "disciplinas" de Foucault) trans-subjetiva. (Esta é uma questão crucial para se decidir se devemos ler Nietzsche como um pensador 
moderno ou pós-moderno. Se ele é um pensador moderno, então acredita que pode haver uma emancipação individual e coletiva em relação ao tipo de "disciplina e cultivo" que tem existido até agora, ou seja, uma emancipação individual e coletiva em relação à "horrível supremacia do absurdo e do acaso a que se tem chamado 'história' até agora" (JGB/BM 203, KSA 5.126); mas se Nietzsche é um pensador pós-moderno, então acredita que não pode haver um sujeito, individual ou coletivo, que possa levar a cabo tal emancipação.)

(iv) Outro tema crucial é a consciência e a natureza social da nossa subjetividade dividida, descentrada. Há muitas passagens em Nietzsche que confirmam que ele concebe o "eu" - ou, mais exatamente, o "si", o "si-próprio" - como sendo intrinsecamente social, mas, além disso, o texto mais importante que Nietzsche, na verdade, publicou sobre a consciência, ou seja, o parágrafo 354 de A gaia ciência, tem como foco principal a tese de que a comunicação entre os membros de uma comunidade humana é uma condição necessária da consciência e, portanto, a consciência é um fenômeno social, não individual. Este fato exige, muito claramente, um diálogo com Hegel e a sua fenomenologia intersubjetiva da autoconsciência. ${ }^{43}$

(v) O parágrafo 354 de $A$ gaia ciência parece tratar a consciência exclusivamente a partir de uma perspectiva de terceira-pessoa, mas, como já argumentei em outro lugar, ${ }^{44}$ a abordagem de Nietzsche ao problema da consciência não exclui a perspectiva da primeira-pessoa porque é uma abordagem de "duplo aspecto". Como Schopenhauer, Nietzsche concebe a terceira - e a primeira-pessoa como perspectivas complementares. Para se responder à pergunta sobre a relação entre o seu conceito de poder e o conceito de poder implícito nas lutas por reconhecimento em Hegel, não há dúvida de que é importante

43 SIEMENS, Herman. "Nietzsche's socio-physiology of the self", op. cit; e CONSTÂNCIO, João. "Nietzsche on Decentered Subjectivity or, the Existential Crisis of the Modern Subject", op. cit. 44 Cf. CONSTÂNCIO, João. "On Consciousness, op. cit.; CONSTÂNCIO, João "Towards a 'Morphology of the Will to Power', op. cit. 
Constâncio, J.

perguntar por que e em que sentido a sua hipótese da vontade de poder não diz respeito apenas ao poder considerado de uma perspectiva de terceira-pessoa, mas também ao sentimento de poder considerado de uma perspectiva de primeira-pessoa. Este sentimento de poder parece ser ocasionada por relações sociais e interpessoais e ser intrinsecamente intersubjetivo.

(vi) Por último, e tal como foi indicado acima, Hegel e Nietzsche descrevem ambos a modernidade como uma época em que a sociedade evolui na direção de um máximo de igualdade. Hegel vê este desenvolvimento histórico como um progresso em direção à liberdade como reconciliação, ou seja, em direção ao reconhecimento recíproco, enquanto Nietzsche o vê como décadence. Em grande medida, esta evolução na direção da igualdade e da decadência consiste, para Nietzsche, no fato de o ser humano se ter tornado um "animal de rebanho", ou de os indivíduos tenderem a ser não indivíduos, mas sim meras "funções do rebanho" (FW/GC 116, KSA 3.475). Por isso, são "atores", e as sociedades modernas são sociedades de atores $(F W / G C 356,361, \mathrm{KSA} 3.595,608) \mathrm{em}$ que cada agente tenta identificar-se absolutamente com o seu papel na sociedade, ou seja, com o que pensa que os outros esperam de si. Ao mesmo tempo, cada agente identifica o outro com o papel que o outro tem na sociedade. Enquanto sociedades de atores, as sociedades modernas são espaços intersubjetivos de não-reconhecimento recíproco, na verdade de reconhecimento-malogrado recíproco. Este é certamente um dos aspectos fundamentais da concepção nietzschiana do "último homem" e do niilismo do "último homem", sobretudo se interpretarmos (como creio que devemos fazer) o "último homem" como a visão de pesadelo de uma humanidade futura privada de "espírito" e de qualquer "sentido do trágico". Pois Nietzsche concebe o sentido do trágico não só como um sentido da finitude do indivíduo, mas também como uma espécie de cuidado com a nossa existência coletiva e o nosso destino como espécie, particularmente 
enquanto espécie marcada pela finitude. O sentido do trágico une a humanidade em torno da imagem de "seu iminente naufrágio como um todo", e, portanto, em torno de algo "completamente universal e suprapessoal", que é "o humano como tal" (WB/Co. Ext., IV, 4, KSA 1.453). Não deveríamos ver neste "sentido do trágico" e neste cuidar do "humano como tal" - que é o oposto do contentamento bovino dos últimos homens, portanto também do seu não-reconhecimento recíproco - uma concepção positiva de reconhecimento recíproco que, afinal, Nietzsche acaba por ter?

\begin{abstract}
The article is an attempt to explore a controversial hypothesis, which can be stated like this: there is a deep affinity hitherto largely unnoticed - between Hegel's conception of struggles for "recognition" [Anerkennung] and Nietzsche's conception of the dynamics of "will to power" [Wille zur Macht]. This hypothesis concerns the ways in which struggle and domination are implicitly involved in the Hegelian notion of recognition, that is: it concerns the intersubjective dynamics of failed-recognition. Struggle and domination (as well as violence) are crucial concepts in Hegel's whole conception of recognition - but they are for him operative concepts, whereas in Nietzsche they become thematic, because the concept of "power" becomes thematic. What the article tries to show is that the Nietzschean hypothesis of "will to power" is relevant for the contemporary debate on "recognition and power" because it enables an adequate description of the intersubjective dynamics in which reciprocal recognition is not achieved and relationships of struggle and domination persist, i.e., what persists is "will to power" qua will to domination. However, this is only so because the Nietzschean hypothesis of "will to power" entails a "doctrine of the affects", and hence a conception of "power" [Macht] in terms of "action at a distance", i.e., in terms of intersubjective influence mediated by perceptions, interpretations, and perspectives. This conception of "power" entails a "recognitive" conception of human desire and human will, and, therefore, it would be wrong to claim that Nietzsche's "will to power" involves the dissolution of powerrelations in trans-subjective processes of domination. Hence the affinity between Hegel and Nietzsche which the article tries to evince.
\end{abstract}

Keywords: Hegel - recognition - power - struggle - domination 
Constâncio, J.

\section{Referências bibliográficas}

ABEL, Günter. "Bewußtsein- Sprache- Natur: Nietzsches Philosophie des Geistes", Nietzsche-Studien 30, Berlin, 2001, pp. 1-43.

BENJAMIN, Jessica. "Senhor and Escravo: The Bonds of Love". In. O'NEILL, J. (Org.). Hegel's Dialectic of Desire and Recognition. New York: SUNY, 1996, pp. 209-222.

BRANCO, Maria João Mayer. "Arte e Filosofia no Pensamento de Nietzsche", Diss., Lisbon: Faculdade de Ciências Sociais e Humanas, Universidade Nova de Lisboa, 2010.

"Nietzsche on Metaphor, Musicality, and Style. From Language to the Life of the Drives". In. CONSTÂNCIO, J./ BRANCO, M.J.M. (eds.). Nietzsche On Instinct and Language. Berlin/Boston: De Gruyter, 2011, pp. 35-59.

."Questioning Introspection: Nietzsche and Wittgenstein on 'The Peculiar Grammar of the Word "I"”. In. CONSTÂNCIO, J./ BRANCO, M.J.M./ RYAN, B. (eds.). Nietzsche and the Problem of Subjectivity. Berlin/ Boston: De Gruyter, 2015, pp. 454-486.

BRINK, Bert van den/ OWEN, David (Eds.) Recognition and Power: Axel Honneth and the Tradition of Critical Social Theory. Cambridge: Cambridge University Press, 2007.

CONSTÂNCIO, João. “On Consciousness: Nietzsche's Departure from Schopenhauer". In. Nietzsche-Studien 40, 2011, p. 1-42.

. (2013a), "Towards a 'Morphology of the Will to Power': Notes on Nietzsche's Conception of Philosophy as 'Psychology". In. MOLDER, M.F./ Soeiro, D./ Fonseca, N. (Eds.). Morphology: Questions on Method and Language. Bern/ Berlin/ Bruxelles/ Frankfurt a.M./ New York/ Oxford/ Wien: Peter Lang, 2013, p. 247-275.

. (2013b), "On Nietzsche's Conception of Philosophy in Beyond Good and Evil: Reassessing Schopenhauer's Relevance". In. BORN, M.E./ PICHLER, A. (Hrgs.). Texturen des Denkens: Nietzsches Inszenierung der Philosophie in 'Jenseits von Gut und Böse'. Berlin/ Boston, de gruyter, 2013, p. 145-164.

$140 \mid$ Cad. Nietzsche, Guarulhos/Porto Seguro, v.37, n.1, p. 88-144, 2016. 
Lutas por reconhecimento e vontade de poder: ...

. "Nietzsche on Decentered Subjectivity or, the Existential Crisis of the Modern Subject". In CONSTÂNCIO, J./ BRANCO, M.J.M./ RYAN, B. (eds.). Nietzsche and the Problem of Subjectivity. Berlin/ Boston: De Gruyter, 2015, p. 279-316.

CONSTÂNCIO, J./ BRANCO, M.J.M./ RYAN, B. Nietzsche and the Problem of Subjectivity (Org.). Berlin/ Boston: De Gruyter, 2015.

. "Introduction to Nietzsche and the Problem of Subjectivity". In. CONSTÂNCIO, J./ BRANCO, M.J.M./ RYAN, B. (Eds.). Nietzsche and the Problem of Subjectivity. Berlin/ Boston: De Gruyter, 2015 pp. 1-45

GEMES, Ken. "Nietzsche on Free Will, Autonomy and the Sovereign Individual". In. Aristotelian Society Supplementary, Volume, 80, 2006, p. 321-338.

GERHARDT, Volker. "Das 'Prinzip des Gleichgewichts'. Zum Verhältnis von Recht und Macht bei Nietzsche". In. GERHARDT, V. Pathos und Distanz. Studien zur Philosophie Friedrich Nietzsches. Stuttgart: Reclam, 1988.

GORI, Pietro. La Visione Dinamica del Mondo, Nietzsche e la filosofia naturale di Boscovich. Napoli: Edizioni La Città del Sole, 2007.

"Psychology without a soul, philosophy without and I. Nietzsche and 19th century Psychophysics (Fechner, Lange, Mach)". In. CONSTÂNCIO, J./ BRANCO, M.J.M./ RYAN, B. (Eds.). Nietzsche and the Problem of Subjectivity. Berlin/ Boston: De Gruyter, 2015, p. 166-195.

HARDIMON, Michael O. Hegel's Social Philosophy: The Project of Reconciliation. Cambridge: Cambridge University Press, 1994.

HARRIS, Henry S. "The Concept of Recognition in Hegel's Jena Manuscripts". In. O'Neill, J. (Ed.). Hegel's Dialectic of Desire and Recognition. New York: SUNY, 1996, pp. 233-252.

HEGEL, G.W.F. Phenomenology of Spirit. Translated by A. V. Miller. Oxford: Clarendon Press, 1977.

. Elements of the Philosophy of Right. Translated by H. B. Nisbet. Cambridge: Cambridge University Press, 2003.

HESSE, Mary B. Forces and Fields, The Concept of Action at a Distance in the History of Physics. New York: Dover, 1962.

Cad. Nietzsche, Guarulhos/Porto Seguro, v.37, n.1, p. 88-144, 2016. | 141 
Constâncio, J.

HONNETH, Axel. The Critique of Power, Reflective Stages in a Critical Social Theory. Transl. by Kenneth Baynes. Cambridge, Massachussets/ London, England: MIT Press, 1991.

. The Struggle for Recognition, The Moral Grammar of Social Conflicts. Transl. by Joel Anderson. Oxford: Polity Press, 1995.

KOJÈVE, Alexandre. Introduction to the Reading of Hegel. Lectures on the Phenomenology of Spirit. assembled by Raymond Queneau, edited by Allan Bloom, translated by James H. Nichols, Jr. Ithaca and London: Cornell University Press, 1980. 2014.

The Notion of Authority (A Brief Presentation). London/ New York: Verso,

LOSURDO, Domenico. Hegel and the Freedom of Moderns. Durham and London: Duke University Press, 2004.

NEUHOUSER, Frederick. Foundations of Hegel's Social Theory. Cambridge MA: Cambridge University Press, 2000.

. "Hegel's Social Philosophy". In. BEISER, Frederick C. The Cambridge Companion to Hegel and Nineteenth-Century Philosophy. Cambridge: Cambridge University Press, 2008, p-204-229.

NIETZSCHE, F. Sämtliche Werke, Kritische Studienausgabe. Herausgegeben von Giorgio Colli und Mazzino Montinari (Berlin: de Gruyter, 1967-1977).

. A gaia ciência. Tradução de Paulo César de Souza. São Paulo: Companhia das Letras, 2001

OTTMAnN, Henning. Philosophie und Politik bei Nietzsche, 2. verbesserte und erweiterte Auflage. Berlin/ New York: de gruyter, 1999.

OWEN, David. Nietzsche, Politics and Modernity. London: Sage, 1995.

. "Nietzsche, Ethical Agency and the Problem of Democracy". In. SIEMENS, H./ ROODT, V. (Eds.). Nietzsche, Power and Politics. Berlin/ New York: de gruyter, 2008, p. 143-167.

PATTEN, Allen. "Social Contract Theory and the Politics of Recognition in Hegel's Political Philosophy". In. WILLIAMS, R. R. (ed). Beyond Liberalism and Communitarianism: Studies in Hegel's Philosophy of Right. New York: SUNY, 2001.

142 | Cad. Nietzsche, Guarulhos/Porto Seguro, v.37, n.1, p. 88-144, 2016. 
Lutas por reconhecimento e vontade de poder: ...

PINKARD, Terry. Hegel's Phenomenology. The Sociality of Reason. Cambridge: Cambridge University Press, 1994.

. Hegel's Naturalism. Mind, Nature, and the Final Ends of Life. Oxford: Oxford University Press, 2012.

PIPPIN, Robert B. Hegel's Practical Philosophy. Rational Agency as Ethical Life. Cambridge: Cambridge University Press, 2008.

."The Paradoxes of Power in the Early Novels of J.M. Coetzee". In. Leist, A./ Singer, P. (Eds.). J.M. Cotzee and Ethics. New York: Columbia, 2010, p. 19-41.

. Nietzsche, Psychology, \& First Philosophy. Chicago/ London: University of Chicago Press, 2010.

. Hegel on Self-consciousness. Desire and Death in the Phenomenology of Spirit. Princeton and Oxford: Princeton University Press, 2011.

“The Expressivist Nietzsche". In. CONSTÂNCIO, J./ BRANCO, M.J.M./ RYAN, B. (Eds.). Nietzsche and the Problem of Subjectivity. Berlin/ Boston: De Gruyter, 2015, p. 654-667.

POELLNER, Peter. Nietzsche and Metaphysics. Oxford: Oxford University Press, 2000.

RICCARDI, Mattia. "Nietzsche on the Embodiment of Mind and Self". In: CONSTÂNCIO, J./ BRANCO, M.J.M./ RYAN, B. (Eds). Nietzsche and the Problem of Subjectivity. Berlin/ Boston: De Gruyter, 2015, p. 533-549.

SIEMENS, Herman. "Nietzsche's socio-physiology of the self". In. CONSTÂNCIO, J./ BRANCO, M.J.M./ RYAN, B. (Eds.). Nietzsche and the Problem of Subjectivity. Berlin/ Boston: De Gruyter, 2015, p. 629-653.

SIEP, Ludwig. "The Struggle for Recognition: Hegel's Dispute with Hobbes in the Jena Writings". In. O'NEILL, J. (Ed.). Hegel's Dialectic of Desire and Recognition. New York: SUNY, 1996, p. 273-288.

. Anerkennung als Prinzip der praktischen Philosophie: Untersuchungen zu Hegels Jenaer Philosophie des Geistes. Freiburg: Alber Verlag, 1979.

SOUSA, L. de/FAUSTINO, M. "Nietzsche and Schopenhauer on the 'Self' and the “Subject”". In. CONSTÂNCIO, J./ BRANCO, M.J.M./ RYAN, B. (Eds.). Nietzsche and the Problem of Subjectivity. Berlin/ Boston: De Gruyter, 2015, p. 131-165. 
Constâncio, J.

STACK, George J. Lange and Nietzsche. Berlin: de gruyter, 1983.

WILLIAMS, Robert R. Recognition: Fichte and Hegel on the Other. New York: SUNY, 1992.

. Hegel's Ethics of Recognition. Berkeley/ Los Angeles/ London: University of California Press, 1997. . Tragedy, Recognition, and the Death of God. Oxford: Oxford University Press, 2012.

Artigo recebido para publicação em 12/07/2015. Artigo aceito para publicação em 04/10/2015.

144| Cad. Nietzsche, Guarulhos/Porto Seguro, v.37, n.1, p. 88-144, 2016. 